\title{
Conditional Conservatism and Labor Investment Efficiency
}

\begin{abstract}
Prior literature documents that asymmetric timely recognition of losses versus gains (also known as conditional conservatism) can induce management to make more efficient investment decisions by mitigating information asymmetry between management and investors and providing early signals about the profitability of projects undertaken. In this paper, we investigate the impact of conservatism on an important investment decision that has been overlooked, namely investment in labor. We find that conservatism is negatively associated with labor investment inefficiency; more specifically, conservatism reduces inefficiency investment practices on the labor market, including over-hiring, under-firing, under-hiring, and over-firing. Our results hold after controlling for managerial ability, corporate governance and other investments.
\end{abstract}

Keywords: Conservatism; Labor Investment Efficiency.

Data Availability: Data are available from the public sources cited in the text. 


\section{INTRODUCTION}

In Basu's (1997) seminal work, conditional conservatism (hereafter, conservatism) is interpreted as companies' reporting of earnings reflecting "bad news" more quickly than "good news", implying systematic differences in reporting earnings between bad news and good news periods. Prior literature documents that conservatism can induce management to make more efficient investment decisions on the capital market by mitigating information asymmetry between management and investors and providing early signals about the profitability of projects undertaken (García Lara, Osma, and Penalva 2016). In this study, we investigate the impact of conservatism on another important investment decision that has been overlooked, namely investment on the labor market.

Labor investment efficiency is worthwhile to study for three reasons. First, labor is a significant cost component of business operations. Improving labor investment efficiency would tell much about a firm's overall investment behavior. Labor cost typically represents two-thirds of economy-wide value added (Bernanke 2004). Specifically, human capital plays an increasingly important role as the information and technology industries dominate the world economy (Pfeffer 1996; Zingales 2000). Second, the adjustment costs associated with labor are relatively lower than capital expenditures (Dixit and Pindyck 1994; Jung, Lee, and Weber 2014). Due to its variable nature, labor investment is liquid and reversible. Managers may thus have greater discretion in hiring and firing decisions. Its variable nature also implies that labor investments can vary significantly from year to year, providing a natural and powerful setting to examine the variation in labor investment efficiency. Third, since all firms have employees, a broad cross-sectional sample of firms can be easily available, allowing research questions to be tested in a more general setting. 
We posit that conservatism improves labor investment efficiency through at least four channels. First, conservatism would mitigate labor inefficiency through reducing the information asymmetry between managers and capital providers about a firm's optimal level of labor investment; it would also provide early signals about the profitability of projects undertaken. Second, by imposing timely recognition of losses, conservatism would act as a disciplining mechanism to prevent or deter inefficient investments. Third, given that conservatism discourages managerial empire-building agendas by constraining wasteful investments, more conservative firms will exhibit less over-hiring or under-firing labor practices. Fourth, conservatism can promote long-term orientation on investment decisions and conservative firms are likely to make more efficient labor investments due to their long-term orientation.

To proxy for conservatism, we use a firm-specific measure following the approach of Khan and Watts (2009) based on Banker, Basu, Byzalov, and Chen (2016) model, which is the modified version of Basu's (1997) piecewise linear regression model that parses out the effect of asymmetric cost behavior. More specifically, asymmetric cost behavior indicates the phenomenon where costs rise more in response to sales increases than they fall for sales decreases. Banker, Basu, Byzalov, and Chen (2016) argue that without controlling for the asymmetric response of costs to sales increases versus decreases, Basu's (1997) piecewise linear regression may erroneously detect reporting conservatism when it actually implies cost stickiness. To proxy for labor investment efficiency, we follow Pinnuck and Lillis (2007) and use the absolute values of abnormal net hiring, which is estimated as the deviation of actual net hiring from its expected level.

We find that conservatism is negatively associated with labor investment inefficiency and thus conservative financial reporting would improve labor investment efficiency. We document that conservatism improves labor investment efficiency by mitigating all four types of labor 
investment inefficiency, including over-hiring, under-firing, under-hiring, and over-firing. Our results hold after controlling for managerial ability, corporate governance and other investments.

This study makes several contributions. First, the results of this study contribute to the emerging literature that examines how financial reporting affects firms' investment decisions, and specifically, how accounting conservatism affects firms' investment efficiency in labor. This study provides direct evidence on the relationship between accounting information and labor investment efficiency. Second, despite the prior literature on the effect of conservatism on capital formation, how conservative accounting affects labor investment decisions is largely unknown. This paper fills in this research gap by investigating how conservatism affects labor investment efficiency, which is a primary component of production. Third, Jung, Lee and Weber (2014) investigate the relationship between accruals quality and labor investment efficiency by looking at the abnormal net hiring/firing based on the labor investment model developed by Pinnuck and Lillis (2007). Our study also contributes to this line of research by providing evidence that another important attribute of financial reporting quality, namely, timely recognition of losses (conservatism), can improve labor investment efficiency. Compared to accruals quality, conservatism can be a more direct disciplinary mechanism that induces management to make efficient labor investment decisions.

This paper proceeds as follows. Section 2 summarizes the prior literature. Section 3 develops the hypotheses. Section 4 describes the research design. Section 5 presents the findings on empirical analyses. Section 6 concludes.

\section{LITERATURE REVIEW}

\subsection{Agency Problem and Labor Investment Efficiency}


Agency theory suggests that due to the misalignment of interests between shareholders and managers, managers may engage in opportunistic activities for their own benefits rather than for shareholders' benefits (Jensen and Meckling 1976). One of the most prominent aspects of the agency problem is managerial empire building, that is, managers increase the size of the firm beyond the optimal level or maintain underutilized resources to increase personal benefits from prestige, power and compensation (Jensen 1986). Besides, managers may not exert as much effort as they would in a first-best world (Holmstr" om 1979). Prior literature linking the agency problem to corporate investments investigates merger and acquisition (Titman, Wei and Xie 2004; Dittmar and Mahrt-Smith 2007; Masulis, Wang and Xie 2007) or capital investments (Biddle and Hillary 2006; McNichols and Stubben 2008; Biddle, Hilary and Verdi 2009). These studies link corporate investments to various monitoring mechanisms to mitigate agency conflicts, including corporate governance, financial reporting quality, or external monitoring provided by analysts. However, the literature on corporate investment behavior mostly overlooks labor investment despite its economic significance. ${ }^{1}$

There is some evidence that corporate governance shapes labor practices including worker pay and hiring/firing decisions. For example, Bertrand and Mullainathan (1999) argue that entrenched managers are likely to pay higher wages to workers and are reluctant to trim an unproductive workforce in order to enjoy private benefits such as lower effort wage bargaining and garner employee loyalty. They test this claim by using antitakeover legislation as a proxy for weakened corporate governance and find consistent evidence that affected firms' wages rise with the passage of antitakeover laws. Similarly, Cronqvist, Heyman, Nilsson, Svaleryd, and Vlachos (2009) find that CEOs with more control pay higher wages to workers and this tendency is more

\footnotetext{
${ }^{1}$ The U.S. Census Bureau's annual survey of Manufacturers reveal that payroll and employee benefits totaled $\$ 785$ billion for 2008, compared to $\$ 166$ billion in capital expenditures.
} 
pronounced if workers are closer to the CEO in hierarchy, geographically closer to headquarters, and associated with a conflict-inclined labor union. These results indicate that managers have their preferred set of labor policies and that corporate governance plays an important role in labor market outcomes.

Some recent studies investigate the link between monitoring mechanisms and labor investment. For example, Jung, Lee, and Weber (2014) find hiring behavior varies with financial reporting quality. More specifically, they find that high quality financial reporting can serve to mitigate agency conflicts and improve investment efficiency. Based on the fact that Selling, General and Administrative (SG\&A) costs largely capture the overhead costs incurred in the corporate offices (e.g., office payroll and expenses), another closely related research is Chen, Hope, $\mathrm{Li}$, and Wang (2011) who focus on SG\&A cost asymmetry to shed light on the impact of the agency problem on corporate resources allocation. According to Anderson, Banker, and Janakiraman (2003), SG\&A cost behave asymmetrically, that is, they increase rapidly in response to the increased demand while they decrease slowly in response to the decreased demand. Drawing on the empire building literature and SG\&A cost asymmetry, Chen, Hope, Li, and Wang (2011) find that SG\&A costs asymmetry increases with the managers' empire building incentives due to the agency problem, and that strong corporate governance mitigates the effects of the agency problem on SG\&A cost asymmetry.

More recently, Ghaly, Dang, and Stathopoulos (2015) investigate how the investment horizon of a firm's institutional shareholders affects the efficiency of its labor investments and find that long-term investors have greater incentives to engage in effective monitoring, which reduces agency conflicts in labor investment choices. Besides, Ben-Nasr and Alshwer (2016) find that labor investment efficiency is positively related to stock price informativeness. They argue 
that stock prices include information that managers do not possess such as information about future investment and growth opportunities, future demand of the firm's products and services, and financing opportunities, which may affect labor investment decisions. Also, more informative stock prices are associated with better external and/or internal monitoring of managers, and hence, mitigate the empire-building problem on the labor market (such as over-hiring or under-firing).

\subsection{Conservatism as a Corporate Governance Mechanism}

Conservatism is viewed as requiring higher verification standards for recognizing good news than bad news (Basu 1997; Watts 2003a, 2003b). Previous research provides ample evidence on the positive governance aspect of conditional conservatism. For example, Ahmed and Duellman (2011) find a positive association between conservatism and board independence. García Lara, Osma, and Penalva (2009) find a positive association between conservatism and corporate governance. Also, conservative reporting is believed to alleviate adverse moral hazard problems in the presence of information asymmetry and agency costs associated with low managerial ownership (Roychowdhury and Watts 2007; LaFond and Watts 2008). Focusing on the banking industry, Leventis, Dimitropoulos, and Owusu-Ansah (2013) find that well-governed banks engage in significantly higher levels of conditional conservatism in their financial reporting practices, suggesting that accounting conservatism serves as a complement to corporate governance in mitigating the opaqueness and intense information asymmetry that plague banks.

In the area of investment efficiency, Francis and Martin (2010) document that conservatism is associated with more efficient acquisition and divestiture decisions, and this benefit is more

pronounced among firms bearing high agency costs. Louis, Sun and Urcan (2012) examine how conservatism affects the market value of excess cash. Since excess cash has the potential to be wasted, the market value of one additional dollar of excess cash holdings is less than a dollar. They 
find that conservative reporting can mitigate the value discount associated with large cash holdings by encouraging a more efficient use of cash. García Lara, Osma, and Penalva (2016) find that more conservative firms are less likely to over-invest or under-invest. More specifically, they argue that conservatism, by forcing timely recognition of losses, alleviates under-investment by facilitating access to additional debt for new investments, and alleviates over-investment by enabling better project selection and earlier abandonment of loss-making projects.

Ahmed and Duellman (2013) hypothesize that because overconfident managers tend to overestimate future returns from their investments and underestimate the negative impacts on firms' cash flows, managerial overconfidence results in delayed loss recognition (i.e., less conditional conservatism). As predicted, they find that managerial overconfidence is negatively associated with conservatism, confirming the link between conservatism and investment efficiency.

\section{HYPOTHESIS DEVELOPMENT}

Among various measures of financial reporting qualities, we believe that the aspect of conservatism can capture a first-order effect of reporting quality on investment efficiency. We expect that conservatism improves labor investment efficiency through four channels: (1) reducing information asymmetry between managers and capital providers; (2) providing a disincentive to engage in inefficient investments through early warning signals about the profitability of projects undertaken; (3) reducing managerial overconfidence; and (4) promoting a long-term orientation in managerial investment decisions.

First, conservatism is known to reduce information asymmetry between managers and capital providers (both debt and equity financing) as bad news will be reflected sooner under more conservative reporting. Labor inputs require capital outlay, which involves financing. Information 
asymmetry exists between managers and capital providers since outsiders have less resources in knowing the optimal level of labor for a firm. This information asymmetry might result in inefficient resource allocation. For example, managers may prefer no layoffs or wage cuts when the operating performance is less satisfactory to enjoy a quiet life and maintain a good relationship with the workforce. Their preference for a certain set of labor policies can be implemented if it goes unnoticed. However, under conservative reporting, bad news will be reflected in earnings sooner and cannot be concealed for long. It will thus be more difficult for managers to justify their reluctance to lay off workers when performance suffers, implying that labor investment efficiency will be improved under conservative reporting. Along the same line, conservatism could facilitate debt and equity financing through its role in reducing information asymmetry. This ease of access to external financing helps firms to hire workers as needed.

Second, conservatism helps provide early warning signals of the project outcome. Watts (2003a) suggests that conservatism allows directors and shareholders to receive early signals about the profitability of projects undertaken. In case of negative NPV projects, such signals could enable managers to intervene in a timely manner and take corrective actions, such as the abandonment of projects or the replacement of managers. Therefore, conservatism provides incentives (disincentives) for ex ante efficient (inefficient) investment decisions and facilitates ex post monitoring of investment decisions. These incentives would help managers adjust their labor investment in a timely manner.

Third, the requirement of timely recognition of losses will reduce managerial overconfidence and discourage managers from producing sales estimates that are not overly optimistic, which serves as a basis for hiring or firing decisions. Since labor costs are mostly variable, labor budgets are usually based on sales forecasts. Therefore, in order to hire the 
appropriate amount of workforce for a given project, managers should be able to foresee the expected sales. Since overestimating future performance and returns from a firm's investments may lead to over-hiring or under-firing, conservatism can promote labor investment efficiency by mitigating the overestimation on sales potential.

Fourth, conservatism can promote a long-term orientation on investment decisions. Selfinterested managers may pursue projects that do not generate positive net present value (NPV) but can bring in short-term benefits that help maintain or boost stock price. Conservatism can mitigate managerial myopia since it provides disincentives to managers to engage in such projects by accelerating the recognition of losses. Ball and Shivakumar (2006) argue that, because of conservatism, losses from poorly performing projects tend to be recognized early during a manager's tenure; therefore, managers are deterred from making a value-destroying investment whose results will be revealed during his or her tenure. In other words, conservatism could potentially promote a long-term orientation on investment decisions since managers of conservative firms are less likely to engage in such investments when reporting losses which are inevitable in a short-term orientation. The long-term orientation is relevant for labor investment because the benefits of labor investments are more visible in a longer term. A short-term-oriented firm can end up under-investing in labor in fear of such investments reducing current earnings and adversely affecting stock prices (Porter 1992; Bushee 1998). Also, short-term-oriented firms may over-invest in labor or retain labor that are not needed with the expectation that they can fool the market and investors at least for a short term. Therefore, conservative firms tend to make more efficient labor investments due to their long-term orientation.

Following the above arguments, we hypothesize that conservatism, by imposing timely recognition of losses, would act as a disciplining mechanism to prevent or deter inefficient 
investments. This would result in the level of labor investment that is close to the one justified by a firm's economic fundamentals - that is, a more efficient labor investment.

Our hypothesis is summarized as follows:

Hypothesis: Conservatism is negatively associated with inefficient investments in labor.

\section{METHODOLOGY}

\subsection{Measure of Labor Investment Inefficiency}

To measure labor investment inefficiency, we first estimate the expected level of net hiring (the percentage change in the number of employees) using the following model (1) according to Pinnuck and Lillis (2007). The absolute value of the residual from this model, $\varepsilon$, represents the abnormal net hire (AbsAbNetHire) and is used as our primary measure of labor investment inefficiency.

$$
\begin{aligned}
& \text { NetHire }_{i, t}=\beta_{0}+\beta_{1} \text { SG }_{i, t-1}+\beta_{2} S_{i, t}+\beta_{3} \Delta R O A_{i, t}+\beta_{4} \Delta R O A_{i, t-1}+\beta_{5} \text { ROA }_{i, t}+\beta_{6} \text { Ret }_{i, t}+\beta_{7} \text { Size }_{i, t-1}+ \\
& \beta_{8} \text { Quick }_{i, t-1}+\beta_{9} \Delta \text { Quick }_{i, t}+\beta_{10} \text { Lev vi,t-1 }_{i, t}+\beta_{11} \text { Lossbin }_{i, t-1}+\beta_{12} \text { Lossbin2 }_{i, t-1}+\beta_{13} \text { Lossbin3 }_{i, t-1}+ \\
& \beta_{14} \text { Lossbin }_{i, t-1}+\beta_{15} \text { Lossbin5 }_{i, t-1}+\varepsilon_{i, t}
\end{aligned}
$$

Where NetHire is the percentage change in the number of employees; $S G$ is the percentage change in sales; ROA is the net income divided by total assets at the beginning of the fiscal year; Ret is the annual buy and hold stock return; Size is the log of market value of equity at the beginning of the fiscal year; Quick is the ratio of cash and short-term investments plus receivables to current liabilities; Lev is the ratio of long term debt to total assets at the beginning of the fiscal year; Lossbin variables (Lossbin1 through Lossbin5) are dummy variables for each 0.005 interval of prior year $R O A$ from 0 to -0.025 (for example, Lossbinl equals one if prior year $R O A$ is between -0.005 and 0, Lossbin2 equals one if prior year ROA is between zero and 0.005 , and so on). The model also includes industry and fixed effects and is estimated annually. 


\subsection{Measure of Conservatism}

We construct a firm-specific measure of conservatism, Cscore, following the approach of Khan and watts (2009) based on Banker, Basu, Byzalov, and Chen (2016) model, which is the modified version of Basu's (1997) piecewise linear regression model that parses out the effect of cost stickiness.

The original Basu (1997) model is as follows:

$$
N I_{t}=\beta_{0}+\beta_{1} D_{t}+\beta_{2} R_{t}+\beta_{3} D_{t} * R_{t}+\varepsilon_{t}
$$

where $N I_{t}$ is net income before extraordinary items divided by market value of equity at the beginning of the fiscal year. $R_{t}$ is 12 -month compound returns ending three months after the end of the fiscal year to remove the market response to the previous year's earnings from the current economic news. $D_{t}$ is an indicator variable and equals one if $R_{t}$ is negative, and zero otherwise. A positive $\beta_{3}$ implies greater conservatism, meaning losses are recognized more quickly than gains.

Banker, Basu, Byzalov, and Chen (2016) modified the original Basu’s (1997) regression model to parse out the effect of cost stickiness, the phenomenon where costs rise more in response to sales increases than they fall for sales decreases. Without controlling for the asymmetric response of costs to sales increases versus decreases, Basu's (1997) piecewise linear regression may erroneously detect reporting conservatism when it actually implies cost stickiness. Specifically, Banker, Basu, Byzalov, and Chen (2016) proposed the following model:

$$
N I_{t}=\alpha_{0}+\alpha_{1} D_{t}+\alpha_{2} R_{t}+\alpha_{3} D_{t} * R_{t}+\beta_{1} D S_{t}+\beta_{2} \Delta S_{t} / P_{t-1}+\beta_{3} D S_{t} * \Delta S_{t} / P_{t-1}+\varepsilon_{t}
$$

Where $D S_{t}$ is a dummy variable that equals one if sales decreased from year $t-1$ to $t$ and zero otherwise, $\Delta S_{t} / P_{t-1}$ is the sales change from year $t-1$ to $t$ that is scaled by the market value of equity at the beginning of the year, and the other variables are as defined previously. 
We adopt the approach of Khan and Watts (2009) to develop a firm-level measure of conservatism (Cscore) by estimating the following annual cross sectional regression model:

$$
\begin{aligned}
& N I_{t}=\beta_{0}+\beta_{1} D_{t}+R_{t}\left(\mu_{1}+\mu_{2} \text { Size }_{t}+\mu_{3} M t B_{t}+\mu_{4} L e v_{t}\right)+D_{t} R_{t}\left(\lambda_{1}+\lambda_{2} \text { Size }_{t}+\lambda_{3} M t B_{t}+\lambda_{4} L e v\right)+\lambda_{1}+ \\
& \left(\delta_{1} \text { Size }_{t}+\delta_{2} M t B_{t}+\delta_{3} \text { Lev }_{t}+\delta_{4} D_{t} \text { Size }_{t}+\delta 5 D t{ }^{*} M t B_{t}+\delta_{6} D_{t} \text { Lev }_{t}\right)+D S_{t}\left(\gamma_{1}+\gamma_{2}\right. \text { Size } \\
& \left.{ }_{t}+\gamma_{3} M t B_{t}+\gamma_{4} L_{\text {Lev }}\right)+\Delta S_{t} / P_{t-1}\left(\gamma_{5}+\gamma_{6} \text { Size }_{t}+\gamma_{7} M t B_{t}+\gamma_{8} L e v_{t}\right)+D S_{t} * \Delta S_{t} / P_{t-1}\left(\gamma_{9}+\gamma_{10} \text { Size }-\right. \\
& \left.{ }_{t}+\gamma_{11} M t B_{t}+\gamma_{12} L_{e v}\right)+\varepsilon_{t}
\end{aligned}
$$

where all variables are as defined previously. Empirical estimators of $\lambda_{1}-\lambda_{4}$ are constant across firms, but vary each year since these estimates are derived from annual cross-sectional regressions. The modified Cscore equals $\lambda_{1}+\lambda_{2}$ Size $_{t}+\lambda_{3} M t B_{t}+\lambda_{4} L e v_{t}$. In other words, the incremental timeliness of annual bad news are linear functions of firm-specific characteristics. Our modified version of Cscore controls for the variation in cost stickiness and takes out this variation from the firm-level Cscore from Khan and Watts (2009) derived from the original Basu (1997) regression.

\subsection{Empirical Model}

We adopt the investment model used by Jung, Lee and Weber (2014) who investigate the link between financial reporting quality and labor investment. We use year fixed effects to control for possible macroeconomic factors and industry fixed effects at the two-digit SIC level to control for industry-wide factors affecting hiring decisions. Industry is defined according to the FamaFrench 48 industry classifications (Fama and French 1997). Specifically, we use the following model to test our hypothesis.

$$
\begin{aligned}
& \text { AbsAbNetHire }_{i, t}=\beta_{0}+\beta_{1} \text { Cscore }_{i, t-1}+\beta_{2} F R Q_{i, t-1}+\beta_{3} M t B_{i, t-1}+\beta_{4} \text { Size }_{i, t-1}+\beta_{5} \text { Quick }_{i, t-1}+ \\
& \beta_{6} \text { Leverage }_{i, t-1}+\beta_{7} \text { Dividend }_{i, t-1}+\beta_{8} \text { stdCFO }_{i, t-1}+\beta_{95} \text { StdSales }_{i, t-1}+\beta_{10} \text { Tangible }_{i, t-1}+\beta_{11} \text { Loss }_{i, t-} \\
& { }_{1}+\beta_{12} \text { Insti }_{i, t-1}+\beta_{13} \text { stdNetHire } e_{i, t-1}+\beta_{14} \text { LaborIntensity }_{i, t-1}+\beta_{15} \text { Union }_{i, t-1}+\beta_{16} \text { AbInvest }_{i, t}+ \\
& \varepsilon_{i, t}
\end{aligned}
$$

Financial reporting quality is first controlled to tease out the effect of financial reporting quality on labor investment efficiency documented by Jung, Lee and Weber (2014). The composite 
measure of financial reporting quality $(F R Q)$ is constructed using three financial reporting quality variables (DisAcc, DisWCA and DisRev). Accrual quality can alleviate information frictions and restrain managers' inefficient investment behaviors. We employ the absolute value of discretionary accruals (DisAcc) (Jones 1991), discretionary working capital accruals (DisWCA), and discretionary revenues (DisRev) (Chen, Hope, Li, and Wang 2011). Details on calculating these three measures are discussed in Appendix B. Other control variables include growth opportunities (MtB), firm size (Size), liquidity (Quick), leverage (Leverage), dividend payout (Dividend), cash flow volatilities (StdCFO), sales volatilities (StdSales), tangibility (Tangible) and loss (Loss). We also include institutional ownership (Insti) to control for the ability of external monitoring mechanisms to mitigate market frictions by reducing information asymmetry between managers and investors. Firms' net hiring volatility (StdNetHire), labor intensity (LaborIntensity) and industry-level unionization rates (Union) are further included to control for the amount of flexibility managers can exercise in hiring decisions. To capture unexpected net hiring originating from other investment decisions, such as capital expenditures and R\&D expenditures, abnormal other investment (AbInvest) is controlled. AbInvest is measured based on the investment expectation model as in Biddle, Hilary, and Verdi (2009), where the sum of capital expenditures, acquisition expenditures, and R\&D expenditures, less cash from the sale of property, plant, and equipment, scaled by total assets at the beginning of the year, is regressed on lagged sales growth expressed in the percentage.

\section{EMPIRICAL RESULTS}

\subsection{Sample}


We have obtained financial statement data from Compustat and stock return data from CSRP. Institutional shareholding data were obtained from Thomson Reuters' CDA/Spectrum database, and industry unionization data were obtained from the Union Membership and Coverage database. ${ }^{2}$ To calculate the financial reporting quality measures (DisAcc, DisWCA, DisRev) based on cash flow statement data, our sample period starts from year 1986 when cash flow data became available in Compustat. We require firms to have positive assets and sales. Financial firms (SIC codes 6000-6999) and utilities (SIC codes 4900-4999) are excluded due to the different nature of financial reporting and investments of these firms. Our sample consists of all firm-year observations from 1986 to 2014 with the necessary information in COMPUSTAT and CRSP to estimate all variables, yielding 31,865 firm-years representing 4,971 firms. To mitigate the influence of outliers, we winsorize all continuous variables at the $1 \%$ and $99 \%$ levels. The sample size is reduced when the test requires corporate governance or managerial ability scores (as discussed in section 5.3.2.).

\subsection{Empirical Results}

\subsubsection{Descriptive Statistics}

\section{[Insert Table 1 Here]}

Table 1 Panel A reports the industry distribution of firm-year observations for the top-five industries in the sample. The top-five industries represented are Business Services (12.5\%), Chips (8.9\%), Wholesale (6.3\%), Computers (6.2\%), and Machinery (5.3\%). Descriptive statistics are provided in Panel B. The mean and median values of our primary variable, AbsAbNetHire, are

\footnotetext{
${ }^{2}$ The Union Membership and Coverage Database, available at www.unionstats.com, is an Internet data resource providing private and public sector labor union membership, coverage, and density estimates compiled from the monthly household Current Population Survey (CPS) using BLS methods. Economy-wide estimates are provided beginning in 1973; estimates by state, detailed industry, and detailed occupation begin in 1983; and estimates by metropolitan area begin in 1986. The Database, constructed by Barry Hirsch (Andrew Young School of Policy Studies, Georgia State University) and David Macpherson (Department of Economics, Trinity University), was created in 2002 and is updated annually (Hirsch and Macpherson 2003).
} 
0.164 and 0.105 , respectively. Correlations are provided in Panel C. Consistent with our hypothesis, AbsAbNetHire is negatively correlated with Cscore, providing initial evidence that conservatism is negatively associated with inefficient investments in labor. Correlations among other variables are generally consistent with prior research. For example, similar with Jung, Lee and Weber (2014), AbsAbNetHire is positively correlated with $s t d C F O$, stdSales, and stdNetHire.

\subsubsection{Primary Results}

[Insert Table 2 Here]

The primary results of estimating model (5) on the entire sample are reported in Table 2 column (1). The estimated coefficient on Cscore is negative and significant (coeff. $=-0.039, p$ value $<0.01$ ), suggesting that conservatism is negatively associated with inefficient investments in labor and thus facilitates more efficient net hiring practices. A coefficient of -0.039 on Cscore means that each unit increase in Cscore leads to an incremental reduction in abnormal net hire. As shown in Table 1 Panel B, the mean of absabNetHire is 0.164 . Therefore, a reduction in abnormal net hire for a unit increase in Cscore represents a $23 \%$ further reduction in abnormal net hiring, which is economically significant. This result supports the argument that conservatism mitigates labor investment.

Consistent with Biddle, Hilary, and Verdi (2009) and Jung, Lee and Weber (2014), the estimated coefficient on $F R Q$ is negative and significant, suggesting that investment inefficiency in labor can be mitigated by high-quality financial reporting, but it is of a smaller magnitude than that on Cscore. For example, the coefficient on FRQ, -0.011, in the Column(1) translates into $7 \%$ reduction in abnormal net hiring for a unit increase in $F R Q$, which represents only a third of the impact of Cscore (23\%). As mentioned earlier, this confirms our belief that conservatism may be a primary force driving the improvement in investment efficiency in labor through its direct disciplinary mechanisms that induce management to act in the best interests of shareholders. 
Consistent with Jung, Lee and Weber (2014), most control variables are significantly associated with inefficient investments in labor. Specifically, firms with lower financial reporting quality $(F R Q)$, smaller size (Size), higher leverage (Leverage), more liquidity (Quick), no dividend payout (Dividend), lower profitability (Loss), and lower institutional ownership (Insti) tend to have less efficient investments in labor. Consistent with the correlation results, AbsAbNetHire is positively associated with stdCFO, stdSales, and stdNetHire, suggesting that greater deviations from the expected level of net hiring is associated with greater volatilities of cash flows, sales, and net hiring practices.

We further examine the association between conservatism and inefficient investment in labor on the over-investment (where the actual net hiring is greater than the expected level) and under-investment (where the actual net hiring is less than the expected level) subsamples and report the results in columns (2) and (3), respectively. The estimated coefficients on Cscore are negative and significant for the over-investment subsample (coeff. $=-0.042, p$-value $<0.01)$ and for the under-investment subsample (coeff. $=-0.040, p$-value $<0.01$ ). A reduction in abnormal net hire for unit increase in Cscore for the overinvestment(underinvestment) subsample represents a $25 \%$ (24\%) further reduction in abnormal net hiring, which is economically significant. These results support the argument that conservatism mitigates both over-investment and under-investment in labor.

\subsection{Robustness Analyses}

5.3.1. Subsamples of Over-hiring, Under-firing, Under-hiring and Over-firing [Insert Table 3 Here]

Following Jung, Lee and Weber (2014), we decompose over- and under- investment in labor into the following four subsamples based on the signs of the abnormal net hiring and the expected level of net hiring. 


\begin{tabular}{l|ll} 
& \multicolumn{1}{|c}{ Positive AbNetHire } & \multicolumn{1}{c}{ Negative AbNetHire } \\
\hline Positive Expected NetHire & $\begin{array}{l}\text { Over-hiring } \\
\text { (Over-investment) }\end{array}$ & $\begin{array}{l}\text { Under-hiring } \\
\text { (Under-investment) }\end{array}$ \\
Negative Expected NetHire & $\begin{array}{l}\text { Under-firing } \\
\text { (Over-investment) }\end{array}$ & $\begin{array}{l}\text { Over-firing } \\
\text { (Under-investment) }\end{array}$
\end{tabular}

We then estimate model (5) on each specific subsample and report the results in Table 3. Overinvestment in labor could manifest managers' empire-building agendas since self-interested managers engage in over-hiring activities to expand the staff or employees beyond the optimal size to gain more security, status and perceived professional achievement (Williamson 1963). Given that conservatism discourages empire-building agendas by constraining inefficient investments, more conservative firms will exhibit less over-hiring or under-firing labor practices. Alternatively, conservatism can reduce under-hiring and over-firing because it can alleviate financing frictions by reducing information asymmetry and reducing adverse selection problems for potential financing providers. Garcia Lara, Osma, and Penalva (2016) predict that conservatism mitigates underinvestment among firms facing financing difficulties and find consistent results. As conservatism facilitates financing for firms prone to underinvest, the likelihood of underinvestment in labor (under-hiring and over-firing) would be curtailed. The estimated coefficients on Cscore are negative and significant, indicating that the negative association between conservatism and inefficient investments in labor holds in all four scenarios - over-hiring, under-firing, under-hiring and over-firing.

\subsubsection{Two Alternative Proxies of Conservatism}

[Insert Table 4 Here]

We use two alternative proxies of conservatism. The first one is the accruals-cash flowsbased measure of conservatism, ACscore, based on Ball and Shivakumar (2005). Similar to the 
main measure of conservatism, we also apply Khan and Watts's (2009) method to estimate a firmyear measure of conservatism by estimating the following regression model.

$$
\begin{aligned}
& A C C_{t}=\beta_{0}+\beta_{1} D C_{t}+C F O_{t}\left(\mu_{1}+\mu_{2} \text { Size }_{t}+\mu_{3} M t B_{t}+\mu_{4} \text { Leverage }_{t}\right)+D C_{t} * C F O_{t}\left(\lambda_{1}+\lambda_{2} \text { Size }_{t}+\lambda\right. \\
& \left.{ }_{3} \mathrm{MtB}_{t}+\lambda_{4} \text { Leverage }_{t}\right)+\left(\delta_{1} \text { Size }_{t}+\delta_{2} \mathrm{MtB}_{t}+\delta_{3} \text { Leverage }_{t}+\delta_{4} D C_{t} * \operatorname{Size}_{t}+\delta_{5} D C_{t} * M t B_{t}+\right. \\
& \left.\delta_{6} D C_{t} * \text { Leverage }_{t}\right)+\varepsilon_{t}
\end{aligned}
$$

Where $A C C_{t}$ is total accruals in year $t$, deflated by the year $t-1$ market value of equity; $C F O_{t}$ is the cash flow from operations $(O A N C F)$ in year $t$ deflated by the year $t$ - 1 market value of equity $\left(C S H O^{*} P R C C_{-} F\right)$, and $D C_{t}$ is a dummy variable and equals one if $C F O_{t}$ is negative, and zero otherwise. Following Khan and Watts (2009), the timeliness of bad news (ACscore) can be expressed as follows:

$$
\text { ACscore }=\beta_{3}=\lambda_{1}+\lambda_{2} \text { Size }_{t}+\lambda_{3} M t B_{t}+\lambda_{4} \text { Leverage }_{t}
$$

The other alternative conservatism proxy is the three-year accumulation of non-operating accruals (NOAs), based on Givoly and Hayn (2000). NOAs can be expressed as follows:

$N O A=($ Net Income + Depreciation $)-(\Delta$ Accounts Receivable $+\Delta$ Inventories $+\Delta$ Prepaid Expenses - $\Delta$ Accounts Payable - $\Delta$ Taxes Payable)

NOAs are deflated by average total assets $(A T)$, averaged over a 3-year period, and then multiplied by negative one. As presented in Table 4, our primary results hold for both alternative proxies, ACscore $($ coeff. $=-0.016, p$-value $<0.01)$ and NOAs $($ coeff. $=-0.022, p$-value $<0.01)$, corroborating the main results.

\subsubsection{Alternative Proxies of Labor Investment Efficiency}

We also use two alternative proxies of labor investment efficiency. Following Jung, Lee and Weber (2014), we use the average of a firm's net hiring over the previous three years, and the industry-median net hiring as expected net hiring to calculate abnormal net hiring. In the 
untabulated results using both alternative proxies, the coefficient on Cscore continues to be negative and significant, corroborating our primary results.

\subsubsection{Controlling for Managerial Ability and Corporate Governance}

[Insert Table 5 Here]

We further control for managerial ability and corporate governance to tease out the effects of managerial ability and corporate governance on conservatism. To proxy for managerial ability, we use the measure, MAscore, developed by Demerjian, Lev, Lewis, and Mcvay (2013). To proxy for corporate governance, we use G-index of Gompers, Ishii, and Metrick (2003). As reported in Table 5, our primary result on the negative association between conservatism and inefficient investments in labor still holds after controlling for managerial ability $($ coeff. $=-0.038, p$-value $<0.01)$ and corporate governance $($ coeff. $=-0.029, p$-value $<0.01)$, confirming that the monitoring effect of conservatism on labor investment efficiency is above and beyond that of managerial ability or corporate governance.

\subsubsection{Controlling for Other Investments}

\section{[Insert Table 6 Here]}

Prior studies document that a firm's financial reporting quality relates to its investment behavior (Biddle and Hilary 2006; Biddle, Hilary, and Verdi 2009). For example, Biddle, Hilary, and Verdi (2009) suggest that higher financial reporting quality can curb managerial incentives to engage in value destroying over-investments by disciplining them. They also argue that high financial reporting quality can alleviate the under-investment problem by allowing constrained firms to attract capital by making their positive net present value (NPV) projects more visible to investors and by reducing adverse selection in stock issuance. Labor is a major production input, and thus labor investment is likely to be positively related to other types of investments (such as capital or R\&D expenditures). To the extent that labor investment is a simple manifestation of 
other types of investments, one may argue that the results documented in this study are not distinguishable from the results documented previously. To address this concern, we conduct a similar test as in Jung, Lee and Weber (2014). The entire sample is divided into two subsamples when net hiring is positively or negatively associated with the change in total investment. If our results are simply driven by other investments, we will find the negative association between conservatism and abnormal net hiring only in the subsample with net hiring positively associated with a change in total investment (that is net hiring is moving in the same direction as total investment). The results documented in Table 6 show that our results hold for both subsamples, suggesting that the primary results are not simply driven by other investments and thus provide supplementary evidence to our primary results.

\subsubsection{Examining SAB No. 101 as an Exogenous Shock of Conservatism}

[Insert Table 7 Here]

The enactment of Staff Accounting Bulletin (SAB) No.101 in 1999 results in the change in the regulatory regime. According to Crawford, Price, and Rountree (2011), accounting conservatism increases during the post-SAB 101 period. Therefore, we use the SAB No.101 as an exogenous shock to increase accounting conservatism to further test the association between conservatism and labor investment inefficiency. Cscore is replaced with an indicator variable $S A B$, that equals one after the enactment of SAB 101 and zero otherwise. Consistent with SAB 101 increasing conservatism, the correlation between Cscore and $S A B$ is positive and significant $($ coeff. $=0.120)$ in our sample. To capture within-firm variation in labor efficiency around the enactment of SAB 101, we drop the year dummies and keep the firm fixed effects for this analysis. As reported in Table 7, SAB is negatively and significantly associated with AbsAbNetHire (coeff.=- 
$0.008, p$-value $<0.01$, confirming that a positive shock to accounting conservatism causes firms to reduce labor inefficiency.

\subsubsection{Propensity Score Matching Analysis}

As a further robustness check, we adopt the propensity-score matching method to more effectively control for the differences in relevant dimensions between the conservative and nonconservative subsamples (Armstrong, Guay, and Weber 2010). Armstrong, Guay, and Weber (2010) argues that the propensity score matching method should be applied when the hypothesized causal variable is an endogenous choice by managers, boards of directors, or other similar parties. Because financial reporting decisions are less likely to be random, we attempt to control for potential selection bias using the propensity-score matching method. If differences in the outcome variable (investment behavior on labor market) between conservative firms and non-conservative firms are due to observable reasons other than conservatism, we expect that the coefficient on Cscore will not be different from zero in a matched sample. Instead, if conservatism does play a role in determining investment behavior on the labor market, then more conservative firms and their matches should exhibit different investment behavior on the labor market.

In the first stage, we include all control variables in the following regression model (6) and estimate the model annually:

$$
\begin{aligned}
& \text { Cscore_D }=\beta_{0}+\beta_{1} F R Q_{i, t-1}+\beta_{2} \text { MtB }_{i, t-1}+\beta_{3} \text { Size }_{i, t-1}+\beta_{4} \text { Quick }_{i, t-1}+\beta_{5} \text { Lev }_{i, t-1}+\beta_{6} \text { Dividend }_{i, t-1}+
\end{aligned}
$$

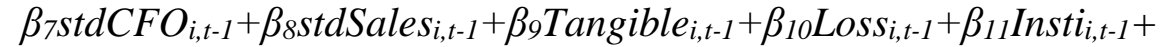

$$
\begin{aligned}
& \beta_{12} \text { stdNetHire }_{i, t-1}+\beta_{13} \text { LaborIntensity }_{i, t-1}+\beta_{14} \text { Union }_{i, t 1}+\beta_{15} \text { AbInvest }_{i, t}+ \\
& \beta_{16} \text { MAScore }_{i, t}+\varepsilon_{i, t}
\end{aligned}
$$

Where Cscore_D equals one if a firm's Cscore is above the industry-year median and zero otherwise. All other variables are as defined in model (5). We obtain the propensity score for each firm-year as the predicted value in model (6). We then match each treatment firm (conservative firm) with a control firm (non-conservative firm) that has the closest score in the same year within 
a distance of 0.10 (without replacement) from the treatment firm's propensity score. If the propensity score match is successful, then we assume that each conservative firm and its matching control firm are similar on all observable dimensions except for the extent of conservatism.

\section{[Insert Table 8 Here]}

Table 8 Panel A reports the first stage results estimating model (6), suggesting that most of the firms' characteristics are significantly related to conservatism. Panel B reports the second stage results comparing the labor investment inefficiency. The coefficient on Cscore, $\beta_{1}$, is negative and significant (coeff.=-0.016, $p$-value<0.01), consistent with labor investment inefficiency is negatively related to conservatism. These results provide corroborating evidence for the primary results discussed in section 5.2.2.

\subsection{Additional Analyses}

\subsubsection{Abnormal Net Hiring and Future Firm Performance}

Following Jung, Lee and Weber (2014), we run the following model which controls for the expected change in profitability that is unrelated to labor inefficiency as well as conservatism.

$\triangle R O A_{\text {iavg }(t+1, t+2, t+3)}=\beta_{0}+\beta_{1}$ AbsNetHire ${ }_{i t}+\beta_{2}$ Cscore $_{i t}+\beta_{3}$ AbsNetHire $i t *$ Cscore $_{i t}+\left(\gamma_{1}+\gamma_{2}\right.$

NetDFE $\left.E_{i t}+\gamma_{3} \mathrm{NegDFE}_{i t} * \mathrm{DFE} E_{i t}+\gamma_{4} \mathrm{Pos} D F E_{i t} * D F E_{i t}\right) * D F E_{i t}+\left(\lambda_{1}+\lambda_{2} \mathrm{NegCE}_{i t}+\lambda_{3} \mathrm{NegC} E_{i t} * C E_{i t}+\right.$ $\left.{ }_{4}{\operatorname{Pos} C E_{i t}}^{*} C E_{i t}\right) * C E_{i t}+\varepsilon_{i t}$

Where $D F E$ is defined as the difference between $R O A$ and expected $R O A$. Expected $R O A$ is the fitted value from a cross-sectional regression of $R O A$ on the natural logarithm of total assets $\left(A T_{t-}\right.$ 1), the natural logarithm of the market-to-book ratio of equity $\left(M T B_{i t-1}\right), R O A_{i t-1}$ and industry dummies. $C E$ is the change in $R O A$ from year $t-1$ to $t$. PosDFE (NegDFE) is a dummy variable that equals one (zero) for positive (negative) DFE. Similarly, $\operatorname{Pos} C E(\mathrm{NegCE})$ is a dummy variable that equals one (zero) for positive (negative) $C E$. The dependent variable is either one-year-ahead 
of the changes in $R O A$ or the average change over the next three years (Chang, Kumar, and Sivaramakrishnan 2006; Jennings, Jung, and Yang 2012).

\section{[Insert Table 9 Here]}

As shown in Table 9 column 1 (using the one-year-ahead change in $R O A$ ), the coefficient on AbsAbNetHire is negative (coeff.=-0.062, $p$-value $<0.01$ ), indicating that labor inefficiencies reduce future profitability. The coefficient on AbsAbNetHire*Cscore is positive (coeff. $=0.190, p$ value $<0.01$ ), indicating conservatism mitigates the negative impact of labor inefficiencies on future profitability. The same results hold for the average changes in $R O A$ over the next three years. Overall, these results suggest that suboptimal net hiring is costly in terms of future performance and lend some additional support to using abnormal net hiring as the primary measure of labor investment inefficiency.

\subsubsection{High vs. Low Unionized Subsamples}

Labor unions have reason to demand high financial reporting quality and more transparent financial reports since they rely on financial information in collective bargaining negotiations. However, organized labor creates incentives for managers to increase information asymmetry in order to hold greater influence over the content of the financial information that unions receive. Thus, to the extent that firms in highly unionized industries are characterized by higher levels of information asymmetry, we may expect that accounting conservatism may play a larger role in mitigating information asymmetry, thus leading to an incremental reduction in labor investment inefficiency.

\section{[Insert Table 10 Here]}

In Table 10, we present the results of estimating model (5) separately for the high and low unionization subsamples, which is based on whether unionization rates for a given industry are 
above or below the median of that year. For brevity, for each subsample, we tabulate only the results for Cscore, along with tests of equivalence across subsamples. In column (1), the coefficient on Cscore is negative and significant for all sample firms. The difference in the coefficients between high $v$ s. low unionized subsamples is not significant $(F$-stat $=-1.12, p$-value $=0.261)$. When the subsample is divided into firms having positive expected net hiring (in column 2) and negative expected net hiring (in column 3), a negative coefficient on Cscore is only found in the subsample with positive expected net hiring (in column 2). Overall, the results indicate that the monitoring benefit of conservatism in labor investment efficiency is equally valuable regardless of the degree of the unionized workforce, but is concentrated in firms with positive economic fundamentals. The fact that there is no significant difference between high and low unionized subsamples (or equivalently, high and low information asymmetry subsamples) may imply that the underlying channel through which conservatism reduces investment inefficiency in labor may be its ability to incentivize managers to act more in line with shareholders' interests, rather than its ability to reduce information asymmetry.

\subsubsection{Considering Labor Adjustment Costs}

The effectiveness of conservatism in increasing labor investment efficiency may vary across the extent of a firm's reliance on skilled labor. Similar to capital expenditures, labor costs associated with recruiting, training, and firing are significant and variable in nature, and thus, are subject to adjustment costs (Oi 1962; Farmer 1985; Hamermesh 1993). Because these costs for high skilled labor are higher than those for the low skilled labor (Ochoa 2013), we expect that conservatism may play a more prominent role in improving labor investment efficiency for firms that require highly skilled labor. 
Following Ochoa (2013), we use Occupational Employment Statistics (OES) data from the Bureau of Labor Statistics and the U.S. Department of Labor's O*NET program classification of occupations according to job skill level, to construct an industry-specific reliance on skilled labor. We divide the sample into the high (above-median) skilled labor and the low (below-median) skilled labor subgroups, where industry is defined using the 3-digit NAICS code.

\section{[Insert Table 11 Here]}

Table 11 shows the results testing how the effectiveness of conservatism in improving investment efficiency varies with the extent of a firm's reliance on skilled labor. While the coefficients on Cscore are significantly negative for both subgroups, the absolute magnitude of the coefficient on Cscore for the high skilled labor subgroup (coeff.=-0.071) is about three times larger and more statistically significant $(p$-value $<0.01)$ than that of the low skilled labor subgroup (coeff. $=-0.024, p$-value $<0.1)$. Also, the difference in the coefficients on Cscore between two subgroups is statistically significant at the $10 \%$ level. The results are consistent with the prediction that the benefit of conservatism in improving labor investment efficiency increases as labor adjustment costs become greater. These results strengthen the link between conservatism and labor investment efficiency.

\section{CONCLUSION}

Prior literature in accounting posits that conservatism can mitigate investment inefficiency in the capital markets. We extend this line of research by examining the effect of conservatism on investment efficiency in the labor market, an important area that has been overlooked. We find that conservatism mitigates investment inefficiency, both over-investment and under-investment in labor. This negative association between conservatism and investment inefficiency in labor 
holds in all possible scenarios of inefficient investment, including over-hiring, under-firing, underhiring, and over-firing in the labor market and also holds after controlling for managerial ability, corporate governance and other investments. Also, the results are both statistically and economically significant. Overall, our results contribute to a growing body of evidence suggesting that financial reporting practices, specifically, conservatism, improves firms' investment decisions in general and in labor in particular.

Our study has several limitations. First, while we find that conservatism is associated with a greater improvement in labor investment efficiency, we note that our study is not designed to identify the underlying mechanism through which conservatism affects labor investment. Second, although we try to address the endogeneity in conservatism using the SAB No.101 as an exogenous shock to increase accounting conservatism, the association between conservatism and labor investment decisions may be driven by some underlying firm characteristics that we do not adequately control for in our empirical specifications. Third, although we use various measures of conditional conservatism and alternative tests to triangulate our results, our inferences ultimately depend on how well the conservatism proxies capture the underlying construct of conservative reporting. Fourth, our results are specific to the United States and may not carry over to other countries with different labor markets. 


\section{References:}

Ahmed, A.S. and S. Duellman. 2011. Evidence on the role of accounting conservatism in monitoring managers? Investment decisions. Accounting \& Finance 51(3): 609-633.

Ahmed, A.S. and S. Duellman. 2013. Managerial overconfidence and Accounting Conservatism. Journal of Accounting Research 51(1): 1-3.

Anderson, M.C., Banker, R.D. and S.N. Janakiraman. 2003. Are selling, general, and adminitrative costs sticky? Journal of Accounting Research 41(1): 47-63.

Armstrong, C.S., Guay, W.R. and J.P. Weber. 2010. The Role of Information and Financial Reporting in Corporate Governance and Debt Contracting. Journal of Accounting and Economics 50(2-3): 179-234.

Ball, R., Shivakumar, L. 2005. Earnings quality in UK private firms: Comparative loss recognition timeliness. Journal of Accounting and Economics 39(1): 83-128.

Ball, R.A.Y. and L. Shivakumar, L. 2006. The role of accruals in asymmetrically timely gain and loss recognition. Journal of Accounting Research 44(2): 207-242.

Banker, R.D., Basu, S., Byzalov, D. and J.Y. Chen, 2016. The confounding effect of cost stickiness on conservatism estimates. Journal of Accounting and Economics 61(1): 203-220.

Basu, S. 1997. The conservatism principle and the asymmetric timeliness of earnings. Journal of Accounting and Economics 24(1): 3-37.

Ben-Nasr, H. and A.A. Alshwer. 2016. Does stock price informativeness affect labor investment efficiency? Journal of Corporate Finance 38: 249-271.

Bernanke, B. 2004. Monetary policy and the economic outlook. Federal Reserve Board Speech delivered at the Meetings of the American Economic Association, San Diego, California, January 4. Available online at http://www.federalreserve.gov/boarddocs/speeches/2004/20040104/default.htm, retrieved Sep 11, 2016.

Bertrand, M. and S. Mullainathan, 1999, Is there discretion in wage setting? Rand Journal of Economics 30(3): 535-554.

Biddle, G. and G. Hilary, 2006. Accounting quality and firm-level capital investment. The Accounting Review 81(5): 963-982.

Biddle, G. C., Hilary, G., and Verdi, R. S. 2009. How does financial reporting quality relate to investment efficiency? Journal of Accounting and Economics 48(2-3): 112-131. 
Bushee, B. 1998. The influence of institutional investors on myopic R\&D investment behavior. The Accounting Review 73(3):305-333.

Chang, C., Kumar, P. and S. Sivaramakrishnan. 2006. Dividend changes, cash flow predictability, and signaling of future cash flows. Working paper, University of Houston.

Chen, F., Hope, O.-K., Li, Q. and X. Wang. 2011. Financial reporting quality and investment efficiency of private firms in emerging markets. The Accounting Review 86(4): 1255-1288.

Crawford, S.S., Price, R.A., and B.R. Rountree. 2011. Regulation and accounting conservatism. Rice University. Working paper.

Cronqvist, H., Heyman, F., Nilsson, M., Svaleryd, H., and J. Vlachos. 2009. Do entrenched managers pay their workers more? Journal of Finance 64 (1): 309-339.

Dechow, P. and I. Dichev. 2002. The quality of accruals and earnings: The role of accrual estimation errors. The Accounting Review 77(Supplement): 35-59.

Demerjian, P., Lev, B., Lewis, M.F. and S.E. Mcvay. 2013. Managerial ability and earnings quality. The Accounting Review 88(2): 463-498.

Dittmar, A. and J. Mahrt-Smith. 2007. Corporate governance and the value of cash holdings. Journal of Financial Economics 83(3): 599-634.

Dixit, A., and R. Pindyck. 1994. Investment under Uncertainty. Princeton, NJ: Princeton University Press.

Fama, E. and K. French. 1997. Industry costs of equity. Journal of Financial Economics 43(2): 153-193.

Farmer, R. 1985. Implicit contracts with asymmetric information and bankruptcy: The effect of interest rates on layoffs. Review of Accounting Studies 52 (3): 427-442.

Francis, J.R. and X. Martin. 2010. Acquisition profitability and timely loss recognition. Journal of Accounting and Economics 49(1-2): 161-178.

Francis, J., LaFond, R., Olsson, P. and K. Schipper. 2005. The market pricing of accruals quality. Journal of Accounting and Economics 39(2): 295-327.

García Lara, J. M., Osma, B. G. and F. Penalva. 2009. Accounting conservatism and corporate governance. Review of Accounting Studies 14(1): 161-201.

García Lara, J. M., Garcia Osma, B. and F. Penalva. 2016. Conditional conservatism and firm investment efficiency. Journal of Accounting and Economics 61:221-238. 
Ghaly, M., Dang, V. A. and K. Stathopoulos. 2015. Institutional Investment Horizons and Labor Investment Efficiency (May 14, 2015). Available at SSRN: https://ssrn.com/abstract=2606272 or http://dx.doi.org/10.2139/ssrn.2606272

Givoly, D. and C. Hayn. 2000. The changing time-series properties of earnings, cash flows and accruals: has financial reporting become more conservative? Journal of Accounting and Economics 29(3): 287-320.

Gompers, P., Ishii, J. and A. Metrick. 2003. Corporate governance and equity prices, Quarterly Journal of Economics 118(1): 107-155.

Hamermesh, D. 1993. Labor Demand. Princeton, NJ: Princeton University Press.

Holmstr“om, B. 1979. Moral hazard and observability, Bell Journal of Economics 10(1): 74-91.

Hirsch. B.T. and D.A. Macpherson. 2003. Union membership and coverage database from the current population survey: note," Industrial and Labor Relations Review 56(2): 349-354.

Jennings, R., Jung, B. and Y. S. Yang. 2012. Costly dividend increases and future prospects: Evidence for firms with weak credit ratings. Working paper, University of Texas at Austin.

Jensen, M.C. 1986. Agency cost of free cash flow, corporate finance, and takeovers. American Economic Review 76(2): 323-329.

Jensen, M.C. and W.H. Meckling. 1976. Theory of the firm: managerial behavior, agency costs, and ownership structure. Journal of Financial Economics 3(4): 305-360.

Jones, J.J. 1991. Earnings management during import relief investigation. Journal of Accounting Research 29(2): 193-228.

Jung, B.C., Lee, W. and D. P. Weber. 2014. Financial reporting quality and labor investment efficiency. Contemporary Accounting Research 31(4): 1047-1076.

Khan, M. and R. L. Watts. 2009. Estimation and empirical properties of a firm-year measure of Account. Conservatism. Journal of Accounting Economics 48(2-3): 132-150.

LaFond, R. and R. Watts. 2008. The information role of conservatism. The Accounting Review 83(2): 447-478.

Leventis, S., Dimitropoulos, P. and S. Owusu-Ansah. 2013. Corporate governance and accounting conservatism: evidence from the banking industry. Corporate Governance: An International Review 21(3): 264-286.

Louis, H., Sun, A.X. and O. Urcan. 2012. Value of cash holdings and Account. Conservatism. Contemporary Accounting Research 29(4): 1249-1271. 
Masulis, R.W., Wang, C. and F. Xie. 2007. Corporate governance and acquirer returns. Journal of Finance 62(4): 1851-1889.

McNichols, M.F. 2002. Discussion of the quality of accruals and earnings: The role of accrual estimation errors. The Accounting Review (Supplement): 77-61.

McNichols, M.F. and S.R. Stubben. 2008. Does earnings management affect firms' investment decisions? The Accounting Review 83(6): 1571-1603.

Ochoa, J. 2013. Labor Heterogeneity, Volatility and Expected Equity Returns. Working paper.

Oi, W. 1962. Labor as a quasi-fixed factor. Journal of Political Economy 70(6): 538-555.

Pfeffer, J. 1996. Competitive Advantage through People: Unleashing the Power of the Work Force. Cambridge, MA: Harvard Business School Press.

Pinnuck, M. and A. Lillis. 2007. Profits versus losses: Does reporting an accounting loss act as a heuristic trigger to exercise the abandonment option and divest employees? The Accounting Review 82(4): 1031-1053.

Porter, M. 1992. Capital choices: Changing the way America invests in industry. Council on Competitiveness/Harvard Business School.

Roychowdhury, S. and R.L. Watts. 2007. Asymmetric timeliness in earnings, market-to-book and conservatism in financial reporting. Journal of Accounting and Economics 44(1-2): 2-31.

Stubben, S. 2010. Discretionary revenues as a measure of earnings management. The Accounting Review 85(2): 695-717.

Titman, S., Wei, K.C.J. and F. Xie. 2004. Capital investments and stock returns. Journal of Financial and Quantitative Analysis 39(4): 677-700.

Watts, L. R. 2003a. Conservatism in Accounting. Part I: Explanations and implications. Accounting Horizon 17(3): 207-221.

Watts, L. R. 2003b. Conservatism in Accounting. Part II: Evidence and Research Opportunities. Accounting Horizon 17(4): 287-301.

Williamson, O. 1963. Managerial discretion and business behavior. The American Economics Review 53(5): 1032-1057.

Zingales,L. 2000. In search of new foundations. Journal of Finance. 55(4): 1623-1654. 


\title{
Appendix A: Variable Measurement
}

\section{Dependent Variables:}

\author{
NetHire $\quad=$ the percentage change in employees. \\ AbNetHire $\quad=$ the residual from model (1). \\ AbsAbNetHire =the absolute value of AbNetHire.
}

\section{Independent Variables:}

Cscore $\quad=\lambda_{1}+\lambda_{2}$ Size $_{t}+\lambda_{3} M t B_{t}+\lambda_{4}$ Leverage $_{t}$, using the coefficients $\lambda_{1}-\lambda_{4}$ derived from the following cross-sectional regression model.

$N I_{t}=\beta_{0}+\beta_{1} D_{t}+R_{t}\left(\mu_{1}+\mu_{2}\right.$ Size $_{t}+\mu_{3} M t B_{t}+\mu_{4}$ Leverage $\left._{t}\right)+D_{t} R_{t}\left(\lambda_{1}+\lambda_{2}\right.$ Size $_{t}+$ $\lambda_{3} M t B_{t}+\lambda_{4}$ Leverage $+\lambda_{1}+\left(\delta_{1}\right.$ Size $_{t}+\delta_{2} M t B_{t}+\delta_{3}$ Leverage $_{t}+\delta_{4} D_{t}$ Size $_{t}+$ $\delta 5 D t^{*} M t B_{t}+\delta_{6} D_{t}$ Leverage $\left._{t}\right)+D S_{t}\left(\gamma_{1}+\gamma_{2}\right.$ Size $_{t}+\gamma_{3} M t B_{t}+\gamma_{4}$ Leverage $\left._{t}\right)+$ $\Delta S_{t} / P_{t 1}\left(\gamma_{5}+\gamma_{6}\right.$ Size $_{t}+\gamma_{7} M t B_{t}+\gamma_{8}$ Leverage $\left._{t}\right)+D S_{t} * \Delta S_{t} / P_{t-1}\left(\gamma_{9}+\gamma_{10}\right.$ Size $_{t}+\gamma_{11} M t B_{t}+$ $\gamma_{12}$ Leverage $\left._{t}\right)+\varepsilon_{t}$

Cscore_D $\quad=1$ if Cscore is above the industry-year median, and 0 otherwise.

ACscore $\quad=\lambda_{1}+\lambda_{2}$ Size $_{t}+\lambda_{3} M t B_{t}+\lambda_{4}$ Leverage $_{t}$, using the coefficients $\lambda_{1}-\lambda_{4}$ derived from the following cross-sectional model.

$A C C_{t}=\beta_{0}+\beta_{1} D C_{t}+C F O_{t}\left(\mu_{1}+\mu_{2}\right.$ Size $_{t}+\mu_{3} M t B_{t}+\mu_{4}$ Leverage $\left._{t}\right)+D C_{t} * C F O_{t}$ $\left(\lambda_{1}+\lambda_{2}\right.$ Size $_{t}+\lambda_{3} \mathrm{MtB}_{t}+\lambda_{4}$ Leverage $\left._{t}\right)+\left(\delta_{1}\right.$ Size $_{t}+\delta_{2} \mathrm{Mt} \mathrm{B}_{t}+\delta_{3}$ Leverage $_{t}+\delta_{4}$ $D C_{t} *$ Size $_{t}+\delta_{5} D C_{t} * M t B_{t}+\delta_{6} D C_{t} *$ Leverage $\left._{t}\right)+\varepsilon_{t}$

$N O A=[($ Net Income + Depreciation $)-(\triangle$ Accounts Receivable $+\Delta$ Inventories $+\Delta$ Prepaid Expenses $-\Delta$ Accounts Payable $-\Delta$ Taxes Payable $)] /$ average total assets, multiplied by negative one.

$S A B=1$ after the enactment of SAB No. 101 and 0 otherwise.

\section{Other Variables:}

$S G$

$R O A$

Ret

Size

Quick

Leverage

Lossbin1

Lossbin2

Lossbin3

Lossbin4

Lossbin5

NI

$R$
$=$ the percentage change in sales.

$=$ return on assets.

$=$ the annual buy and hold stock returns.

$=$ the logarithm of market value of equity at the beginning of the year.

$=$ the ratio of cash and short-term investments plus receivables to current liabilities.

$=$ the ratio of long-term debt to total assets at the beginning of the year.

$=1$ if prior year $R O A$ is between -0.005 and 0 and 0 otherwise.

$=1$ if prior year $R O A$ is between 0 and 0.005 and 0 otherwise.

$=1$ if prior year $R O A$ is between 0.005 and 0.010 and 0 otherwise.

$=1$ if prior year $R O A$ is between 0.010 and 0.015 and 0 otherwise.

$=1$ if prior year $R O A$ is between 0.015 and 0.020 and 0 otherwise.

$=$ net income before extraordinary items divided by market value of equity at the beginning of the year.

$=$ the 12-month compound returns ending 3 months after the end of the year. 


\begin{tabular}{|c|c|}
\hline$D$ & $=1$ if $R$ is negative and 0 otherwise. \\
\hline$S$ & $=$ sales revenue. \\
\hline$D S$ & $=1$ if sales decrease for the prior year to the current year and 0 otherwise. \\
\hline$P$ & $=$ stock price at the ending of the year. \\
\hline$M t B_{t}$ & $=$ market to book ratio. \\
\hline$F R Q$ & $\begin{array}{l}=\text { the aggregate measure of three financial reporting qualities variables } \\
(\text { PerfDA, DisWCA, DisRev), summing the percentile ranks of these three } \\
\text { variables, as described in Appendix B. }\end{array}$ \\
\hline Dividend & $=$ dividend payout ratio. \\
\hline stdCFO & $=$ standard deviation of cash flow of operations. \\
\hline stdSales & $=$ standard deviation of sales. \\
\hline Tangible & $=$ the ratio of PP\&E to total assets. \\
\hline Loss & $=1$ if $R O A$ is negative, and 0 otherwise. \\
\hline Insti & =institutional ownership ratio. \\
\hline stdNetHire & $=$ standard deviation of NetHire. \\
\hline LaborIntensity & $=$ the number of employees divided by total assets at the end of last year. \\
\hline Union & $=$ industry-level rate of labor unionization. \\
\hline AbInvest & $\begin{array}{l}=\text { abnormal other investment, measured based on the investment expectation } \\
\text { model as in Biddle, Hilary, and Verdi (2009). }\end{array}$ \\
\hline MAscore & $\begin{array}{l}=\text { the managerial ability score as developed by Demerjian, Lev, Lewis, and } \\
\text { Mcvay (2013). }\end{array}$ \\
\hline$G$ & $=$ G-index as in Gompers, Ishii, and Metrick (2003). \\
\hline Industry & $=$ the 48 industries defined by Fama and French (1997). \\
\hline$D F E$ & $\begin{array}{l}=\text { the difference between } R O A \text { and the expected } R O A \text {, which is the fitted value } \\
\text { from a cross-sectional regression of } R O A \text { on the natural logarithm of total } \\
\text { assets }\left(A T_{t-1}\right) \text {, the natural logarithm of the market-to-book ratio of equity } \\
\left(M T B_{i t-1}\right), R O A_{i t-1} \text { and industry dummies. }\end{array}$ \\
\hline PosDFE & $=1$ if $D F E$ is positive and 0 otherwise. \\
\hline NegDFE & $=1$ if $D F E$ is negative and 0 otherwise. \\
\hline$C E$ & $=$ the change in $R O A$ from year $t-1$ to $t$. \\
\hline PosCE & $=1$ if $C E$ is positive and 0 otherwise. \\
\hline $\mathrm{NegCE}$ & $=1$ if $C E$ is negative and 0 otherwise. \\
\hline
\end{tabular}




\section{Appendix B: Measures of the Financial Reporting Quality (FRQ)}

$F R Q$ is an aggregate measure of the following three measures of financial reporting quality, summing the percentile ranks of these three variables.

1. Discretionary accruals (DisAcc) (Jones, 1991).

DisAcc is estimated cross-sectionally each year using all firm-years in the same two-digit SIC code.

$$
T A=\alpha+\beta_{1} 1 / \text { TotalAssets }_{i, t-1}+\beta_{2}\left(\Delta \operatorname{Rev}_{i, t}-\Delta A R_{i, t}\right)+\beta_{3} P P E_{i, t}+\varepsilon_{i, t}
$$

Where $T A=$ total accruals=net income minus cash flow from operations, TotalAssets=total assets, $\triangle R e v=$ change in revenues scaled by lagged total assets, $\triangle A R=$ change in accounts receivable scaled by lagged total assets, and $P P E=$ gross value of PPE scaled by lagged total assets. Residuals from the above model are modified Jones-model discretionary accruals (Jones, 1991).

2. Discretionary working capital accruals (DisWCA) (Chen, Hope, Li, and Wang, 2011)

Dechow and Dichev (2002) develop a model for expected accruals and interpret the deviation from this expected value as the estimation error in accruals. This measure focuses on the strength of the relation between current accruals and past, present, and future cash flows. We use the Dechow-Dichev model as modified by McNichols (2002) and Francis, LaFond, Olsson, and Schipper (2005), adjusting for negative cash flows (Ball and Shivakumar 2006; Givoly and Hayn, 2000). The following model is estimated for each industry-year with at least 20 observations:

$$
\begin{aligned}
& W C A_{i, t}=a_{0}+a_{1} O C F_{i, t 1}+a_{2} O C F_{i, t}+a_{3} O C F_{i, t+l}+a_{4} \Delta R e v_{i, t}+a_{5} P P E_{i, t}+a_{6} \Delta O C F_{i, t}+ \\
& a_{7} O C F_{i, t} * \triangle O C F_{i, t}+\varepsilon_{i, t}
\end{aligned}
$$

Where $W C A=$ working capital accruals=the change in non-cash current assets minus the change in current liabilities other than short-term debt and taxes payable, scaled by lagged total assets; $O C F=$ cash flow from operations=the sum of net income, depreciation, and amortization, minus $W C A$, all scaled by lagged total assets (Chen, Hope, Li, and Wang 2011); $\Delta R e v=$ annual change in revenues scaled by lagged total assets; $P P E=$ property, plant, and equipment, scaled by lagged total assets; and $\triangle O C F=$ an indicator variable for negative operating cash flows. The residuals $\varepsilon_{i, t}$ represent the estimation errors in the current accruals that are not associated with operating cash flows and that cannot be explained by the change in revenue and the level of PPE. WCA is the absolute value of $\varepsilon_{i, t}$.

\section{Discretionary Revenue (DisRev) (Chen, Hope, Li, and Wang 2011)}

We use discretionary revenues based on McNichols and Stubben (2008) and Stubben (2010). We use the following regression for each industry-year with at least 20 observations:

$$
\Delta A R_{i, t}=a_{0}+a_{1} \Delta \operatorname{Rev} v_{i, t}+\varepsilon_{i, t}
$$

Where $\Delta A R=$ the annual change in accounts receivable and $\Delta R e v=$ the annual change in revenues, each scaled by lagged total assets. DisRev are the residuals $\varepsilon_{i, t}$.

All these three variables are multiplied by negative one so that greater values represent better quality of financial reporting and information environment. 
TABLE 1

Industry Distribution, Descriptive Statistics and Correlations

Panel A: Industry Distribution

\begin{tabular}{lc}
\hline \multicolumn{1}{c}{ Industry } & $\begin{array}{c}\text { Percentage of } \\
\text { firm-years }\end{array}$ \\
\cline { 2 - 2 } Business Services & $12.5 \%$ \\
Chips & $8.9 \%$ \\
Wholesale & $6.3 \%$ \\
Computers & $6.2 \%$ \\
Machinery & $5.3 \%$ \\
Firms from the Top-5 Industries & $\mathbf{3 9 . 3 \%}$ \\
\hline
\end{tabular}

Panel B: Descriptive Statistics

\begin{tabular}{|c|c|c|c|c|c|c|}
\hline Variables & $\mathbf{N}$ & Mean & Std. Dev. & $25^{\text {th }}$ & Median & $75^{\text {th }}$ \\
\hline AbsAbNetHire $_{t}$ & 31,865 & 0.164 & 0.181 & 0.047 & 0.105 & 0.210 \\
\hline Cscore $_{t-1}$ & 31,865 & 0.117 & 0.150 & 0.050 & 0.117 & 0.194 \\
\hline$F R Q_{t-1}$ & 31,865 & -0.504 & 0.291 & -0.667 & -0.667 & -0.333 \\
\hline$M t B_{t-1}$ & 31,865 & 1.840 & 1.470 & 1.085 & 1.431 & 2.081 \\
\hline Size $_{t-1}$ & 31,865 & 5.401 & 1.898 & 4.024 & 5.313 & 6.675 \\
\hline Quick $_{t-1}$ & 31,865 & 1.836 & 1.930 & 0.839 & 1.272 & 2.155 \\
\hline Leverage $_{t-1}$ & 31,865 & 0.189 & 0.225 & 0.004 & 0.127 & 0.292 \\
\hline Dividend $_{t-1}$ & 31,865 & 0.324 & 0.468 & 0.000 & 0.000 & 1.000 \\
\hline$s t d C F O_{t-1}$ & 31,865 & 0.064 & 0.054 & 0.029 & 0.050 & 0.083 \\
\hline stdSales $_{t-1}$ & 31,865 & 0.310 & 0.319 & 0.107 & 0.206 & 0.391 \\
\hline Tangible $_{t-1}$ & 31,865 & 0.573 & 0.444 & 0.256 & 0.466 & 0.772 \\
\hline $\operatorname{LosS}_{t-1}$ & 31,865 & 0.261 & 0.439 & 0.000 & 0.000 & 1.000 \\
\hline stdNetHire $_{t-1}$ & 31,865 & 0.194 & 0.191 & 0.068 & 0.135 & 0.249 \\
\hline LaborIntensity $_{t-1}$ & 31,865 & 0.011 & 0.041 & 0.003 & 0.006 & 0.011 \\
\hline Union $_{t-1}$ & 31,865 & 0.050 & 0.099 & 0.000 & 0.000 & 0.056 \\
\hline Instit-1 $_{1}$ & 31,865 & 0.464 & 0.292 & 0.216 & 0.451 & 0.693 \\
\hline abInvest $t_{t-1}$ & 31,865 & -0.025 & 0.114 & -0.102 & -0.039 & 0.030 \\
\hline MAscore & 31,406 & 0.564 & 0.271 & 0.300 & 0.600 & 0.800 \\
\hline Gscore $_{t-1}$ & 15,617 & -8.585 & 2.688 & -10.000 & -9.000 & -7.000 \\
\hline
\end{tabular}


Panel C: Pearson Correlation

\begin{tabular}{|c|c|c|c|c|c|c|c|c|c|c|c|c|c|c|c|c|c|c|}
\hline Variables & 2. & 3. & 4. & 5. & 6. & 7. & 8. & 9. & 10. & 11. & 12. & 13. & 14. & 15. & 16. & 17. & 18. & 19. \\
\hline 1.AbsAbNetHire & 0.05 & -0.02 & 0.06 & -0.11 & 0.27 & 0.04 & -0.14 & 0.14 & 0.10 & -0.02 & 0.11 & 0.13 & -0.01 & -0.01 & -0.08 & 0.04 & 0.02 & 0.07 \\
\hline 2. Cscore $_{t-1}$ & & -0.03 & -0.24 & -0.59 & -0.03 & -0.02 & -0.21 & 0.15 & 0.11 & -0.06 & 0.20 & 0.08 & 0.04 & -0.01 & -0.41 & -0.06 & -0.06 & 0.09 \\
\hline $3 . F R Q_{t-1}$ & & & 0.02 & 0.03 & -0.04 & -0.01 & 0.00 & 0.01 & 0.00 & 0.01 & 0.10 & 0.00 & -0.01 & 0.03 & 0.03 & 0.01 & 0.05 & -0.02 \\
\hline $4 . M t \tilde{B}_{t-1}$ & & & & 0.25 & 0.20 & -0.15 & -0.05 & 0.14 & 0.03 & -0.09 & -0.10 & -0.04 & -0.02 & -0.09 & 0.17 & 0.11 & 0.24 & 0.08 \\
\hline 5.Size ${ }_{t-1}$ & & & & & 0.03 & 0.07 & 0.31 & -0.21 & -0.13 & 0.05 & -0.17 & -0.06 & -0.09 & -0.05 & 0.64 & 0.06 & 0.03 & -0.19 \\
\hline 6.Quick $k_{t-1}$ & & & & & & -0.19 & -0.13 & 0.08 & 0.04 & -0.22 & -0.01 & -0.01 & -0.03 & -0.11 & 0.09 & -0.03 & 0.11 & 0.14 \\
\hline 7.Leverage ${ }_{t-1}$ & & & & & & & 0.04 & -0.17 & -0.06 & 0.31 & 0.00 & 0.13 & -0.04 & 0.11 & 0.04 & 0.19 & -0.21 & -0.04 \\
\hline 8.Dividend Di-1 & & & & & & & & -0.25 & -0.18 & 0.19 & -0.20 & -0.18 & 0.01 & 0.18 & 0.12 & -0.05 & 0.01 & -0.24 \\
\hline 9.stdCFO $\mathrm{O}_{t-1}$ & & & & & & & & & 0.35 & -0.16 & 0.17 & 0.14 & -0.01 & -0.10 & -0.17 & 0.03 & 0.11 & 0.12 \\
\hline 10.stdSalest-1 & & & & & & & & & & -0.20 & 0.09 & 0.36 & 0.04 & -0.06 & -0.12 & 0.03 & 0.02 & 0.11 \\
\hline 11.Tangiblet-1 & & & & & & & & & & & -0.08 & -0.09 & 0.00 & 0.15 & -0.01 & 0.19 & -0.11 & -0.11 \\
\hline 12.Losst-1 & & & & & & & & & & & & 0.13 & -0.02 & -0.06 & -0.15 & -0.03 & -0.10 & 0.03 \\
\hline 13.stdNetHiret-1 & & & & & & & & & & & & & 0.00 & -0.05 & -0.04 & 0.02 & -0.07 & 0.09 \\
\hline 14.LaborIntensityt-1 & & & & & & & & & & & & & & 0.00 & -0.07 & -0.04 & 0.00 & 0.00 \\
\hline 15.Uniont-1 & & & & & & & & & & & & & & & -0.14 & 0.04 & -0.03 & 0.00 \\
\hline 16.Instit-1 & & & & & & & & & & & & & & & & 0.07 & -0.03 & -0.13 \\
\hline 17.abInvest $t_{t-1}$ & & & & & & & & & & & & & & & & & 0.05 & 0.06 \\
\hline 18.MAscore & & & & & & & & & & & & & & & & & & 0.03 \\
\hline
\end{tabular}

Panel A reports the distribution of firm-year observations and unique firms from the top-five industries. Industry is defined according to the Fama-French 48 industry classification (Fama and French, 1997). Panel B shows the descriptive statistics of variables. Panel C shows the Pearson correlations among variables. Italic font denotes correlations that are statistically significant at $p<0.05$. All variables are defined in Appendix A. 
TABLE 2

The Effect of Conservatism on Labor Investment Efficiency

The regression model:

AbsAbNetHire $_{t}=\beta_{0}+\beta_{1}$ Cscore $_{i t-1}+\beta_{2}$ FR $_{i t-1}+\beta_{3}$ MtB $_{i t-1}+\beta_{4}$ Size $_{i t-1}+\beta_{5}$ Quick $_{i t-1}+\beta_{6}$ Leverage $_{i t-1}+\beta_{7}$ Dividend $_{i t-1}+$

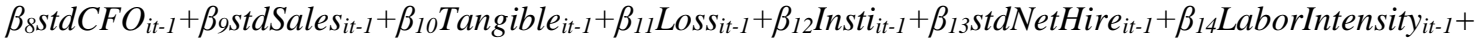
$\beta_{15}$ Union $_{i t-1}+\beta_{16}$ AbInvest $_{i t}+\varepsilon_{i t}$

\begin{tabular}{|c|c|c|c|c|c|c|c|c|c|}
\hline \multirow[t]{2}{*}{ Variables } & \multicolumn{3}{|c|}{$\begin{array}{c}(1) \\
\text { Dependent Variable = } \\
\text { Abnormal Net Hiring } \\
\quad(\text { abNetHiring })\end{array}$} & \multicolumn{3}{|c|}{$\begin{array}{c}(2) \\
\text { Overinvestment in } \\
\text { Labor Subample } \\
(\text { abNetHiring>0) }\end{array}$} & \multicolumn{3}{|c|}{$\begin{array}{c}(3) \\
\text { Underinvestment in } \\
\text { Labor Subsample } \\
(\text { abNetHiring<0) }\end{array}$} \\
\hline & Coeff. & & $t$-stat & Coeff. & & t-stat & Coeff. & & t-stat \\
\hline Intercept & 0.099 & $* * *$ & 6.01 & 0.129 & $* * *$ & 5.77 & 0.100 & $* * *$ & 4.32 \\
\hline Cscore $_{t-1}$ & -0.039 & $* * *$ & -6.33 & -0.042 & $* * *$ & -4.79 & -0.040 & $* * *$ & -4.55 \\
\hline$F R Q_{t-1}$ & -0.011 & $* * *$ & -3.68 & -0.004 & & -0.95 & -0.017 & $* * *$ & -4.16 \\
\hline$M t \widetilde{B}_{t-1}$ & 0.003 & $* * *$ & 3.00 & 0.006 & $* * *$ & 3.77 & 0.001 & & 1.05 \\
\hline Size $_{t-1}$ & -0.012 & $* * *$ & -12.14 & -0.013 & $* * *$ & -9.56 & -0.012 & $* * *$ & -8.93 \\
\hline Quick $_{t-1}$ & 0.027 & $* * *$ & 34.74 & 0.009 & $* * *$ & 4.90 & 0.032 & $* * *$ & 30.44 \\
\hline Leverage $_{t-1}$ & 0.060 & $* * *$ & 9.63 & 0.018 & $*$ & 1.95 & 0.079 & $* * *$ & 9.39 \\
\hline Dividend $_{t-1}$ & -0.012 & $* * *$ & -5.56 & -0.017 & $* * *$ & -4.97 & -0.010 & $* * *$ & -3.80 \\
\hline$s t d C F O_{t-1}$ & 0.213 & $* * *$ & 8.90 & 0.246 & $* * *$ & 6.63 & 0.185 & $* * *$ & 6.04 \\
\hline stdSales $_{t-1}$ & 0.010 & $* *$ & 2.45 & 0.015 & $* *$ & 2.32 & 0.007 & & 1.48 \\
\hline Tangible $_{t-1}$ & -0.004 & & -1.27 & -0.019 & $* * *$ & -3.83 & 0.004 & & 0.80 \\
\hline $\operatorname{Loss}_{t-1}$ & 0.035 & $* * *$ & 14.47 & 0.011 & $* * *$ & 3.08 & 0.053 & $* * *$ & 16.59 \\
\hline stdNetHire $_{t-1}$ & 0.070 & $* * *$ & 10.74 & 0.070 & $* * *$ & 6.83 & 0.070 & $* * *$ & 8.53 \\
\hline LaborIntensity $_{t-1}$ & 0.016 & & 0.55 & -0.146 & $* *$ & -2.41 & 0.049 & & 1.44 \\
\hline Union $_{t-1}$ & -0.026 & $* *$ & -2.25 & 0.013 & & 0.72 & -0.064 & $* * *$ & -4.34 \\
\hline Insti $_{t-1}$ & -0.023 & $* * *$ & -5.08 & -0.015 & $* *$ & -2.27 & -0.029 & $* * *$ & -4.56 \\
\hline abInvest $_{t-1}$ & 0.072 & $* * *$ & 7.15 & 0.015 & & 0.96 & 0.122 & $* * *$ & 9.44 \\
\hline Year Fixed Effects & & Yes & & & Yes & & & Yes & \\
\hline Industry Fixed Effects & & Yes & & & Yes & & & Yes & \\
\hline Adj. $R^{2}$ & & $4.03 \%$ & & & $.63 \%$ & & & $5.68 \%$ & \\
\hline$N$ & & 1,865 & & & 4,424 & & & 7,441 & \\
\hline
\end{tabular}

This table presents the results of estimating model (5). The results for the full sample, the overinvestment subsample (where the actual net hiring is greater than the expected level), and underinvestment subsample (where the actual net hiring is less than the expected level) are provided in columns (1), (2) and (3), respectively. All variables are as defined in Appendix A. $p$-values are based on two-tailed tests, with standard errors clustered by firm. 
TABLE 3

The Effect of Conservatism on Over- and Under- Hiring (and Firing)

The regression model:

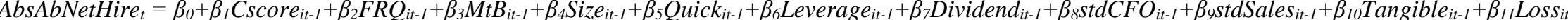
${ }_{1}+\beta_{12}$ Insti $_{i t-1}+\beta_{13 \text { stdNetHire }}{ }_{i t-1}+\beta_{14}$ LaborIntensity $_{i t-1}+\beta_{15}$ Union $_{i t-1}+\beta_{16}$ AbInvest $_{i t}+\varepsilon_{i t}$

\begin{tabular}{|c|c|c|c|c|c|c|c|c|c|c|c|c|}
\hline \multirow[t]{2}{*}{ Variables } & \multicolumn{3}{|c|}{ (1) } & \multicolumn{3}{|c|}{$\begin{array}{c}\text { (2) } \\
\text { Underfiring }\end{array}$} & \multicolumn{3}{|c|}{$\begin{array}{c}\text { (3) } \\
\text { Underhiring }\end{array}$} & \multicolumn{3}{|c|}{$\begin{array}{c}\text { (4) } \\
\text { Overfiring }\end{array}$} \\
\hline & Coeff. & & $t$-stat & Coeff. & & $t$-stat & Coeff. & & t-stat & Coeff. & & t-stat \\
\hline Intercept & 0.050 & & 1.06 & 0.107 & **** & 3.70 & 0.146 & $* * *$ & 5.30 & 0.103 & $* * *$ & 2.78 \\
\hline Cscore $_{t-1}$ & -0.024 & $*$ & -1.83 & -0.043 & $* * *$ & -4.06 & -0.050 & $* * *$ & -4.27 & -0.027 & $* *$ & -2.15 \\
\hline$F R Q_{t-1}$ & 0.006 & & 0.85 & -0.025 & $* * *$ & -5.37 & -0.008 & & -1.36 & 0.005 & & 0.66 \\
\hline$M t \widetilde{B}_{t-1}$ & 0.003 & & 1.58 & 0.001 & & 0.59 & 0.006 & $* * *$ & 2.66 & 0.008 & $* * *$ & 3.22 \\
\hline Size $_{t-1}$ & -0.009 & $* * *$ & -4.00 & -0.013 & $* * *$ & -7.61 & -0.015 & $* * *$ & -8.68 & -0.008 & $* * *$ & -4.11 \\
\hline Quick $_{t-1}$ & 0.031 & $* * *$ & 30.35 & 0.033 & $* * *$ & 24.10 & 0.010 & $* * *$ & 4.92 & 0.004 & & 1.22 \\
\hline Leverage $_{t-1}$ & 0.095 & $* * *$ & 9.23 & 0.073 & $* * *$ & 7.31 & 0.030 & $* * *$ & 2.65 & -0.008 & & -0.51 \\
\hline Dividend $_{t-1}$ & -0.010 & $*$ & -1.77 & -0.011 & $* * *$ & -3.25 & -0.017 & $* * *$ & -3.76 & -0.016 & $* * *$ & -3.17 \\
\hline$s t d C F O_{t-1}$ & 0.217 & $* * *$ & 4.63 & 0.181 & $* * *$ & 5.06 & 0.219 & $* * *$ & 4.83 & 0.306 & $* * *$ & 4.83 \\
\hline stdSales $_{t-1}$ & 0.009 & & 1.24 & 0.007 & & 1.25 & 0.016 & $* *$ & 2.00 & 0.014 & & 1.29 \\
\hline Tangible $_{t-1}$ & 0.01 & $* *$ & 2.17 & -0.000 & & -0.04 & -0.025 & $* * *$ & -3.84 & -0.005 & & -0.66 \\
\hline $\operatorname{Loss}_{t-1}$ & 0.047 & $* * *$ & 9.56 & 0.055 & $* * *$ & 14.24 & 0.008 & & 1.58 & 0.019 & $* * *$ & 3.38 \\
\hline stdNetHire $_{t-1}$ & 0.041 & $* * *$ & 3.60 & 0.083 & $* * *$ & 8.10 & 0.076 & $* * *$ & 5.95 & 0.054 & $* * *$ & 3.22 \\
\hline LaborIntensity $_{t-1}$ & 0.050 & & 0.94 & 0.049 & & 1.23 & -0.191 & $* *$ & -2.47 & -0.064 & & -0.54 \\
\hline Union $_{t-1}$ & -0.086 & $* * *$ & -2.99 & -0.056 & $* * *$ & -3.17 & 0.036 & & 1.38 & -0.031 & & -1.20 \\
\hline Instit-1 & -0.038 & $* * *$ & -3.66 & -0.027 & $* * *$ & -3.59 & -0.017 & $*$ & -1.90 & -0.009 & & -1.07 \\
\hline abInvest $_{t-1}$ & 0.109 & $* * *$ & 5.21 & 0.126 & $* * *$ & 8.38 & 0.009 & & 0.47 & 0.035 & & 1.21 \\
\hline $\begin{array}{l}\text { Year Fixed } \\
\text { Effects }\end{array}$ & & Yes & & & Yes & & & Yes & & & Yes & \\
\hline $\begin{array}{l}\text { Industry Fixed } \\
\text { Effects }\end{array}$ & & Yes & & & Yes & & & Yes & & & Yes & \\
\hline$A d j . R^{2}$ & & $2.74 \%$ & & & $4.55 \%$ & & & $.49 \%$ & & & $63 \%$ & \\
\hline$N$ & & 4,742 & & & 2,699 & & &, 745 & & & 679 & \\
\hline
\end{tabular}

This table reports the results of estimating model (5) on four subsamples (overhiring, undefiring, underhiring and overhiring) of the sample. The four subsamples are defined as Jung et al. (2014). All variables are as defined in Appendix A. p-values are based on two-tailed tests, with standard errors clustered by firm. 
TABLE 4

\section{Alternative Proxies of Conservatism}

The regression model:

AbsAbNetHire $_{t}=\beta_{0}+\beta_{1}$ Cscore $_{i t-1}+\beta_{2}$ FR $_{i t-1}+\beta_{3}$ MtB $_{i t-1}+\beta_{4}$ Size $_{i t-1}+\beta_{5}$ Quick $_{i t-1}+\beta_{6}$ Leverage $_{i t-1}+\beta_{7}$ Dividend $_{i t-1}+$

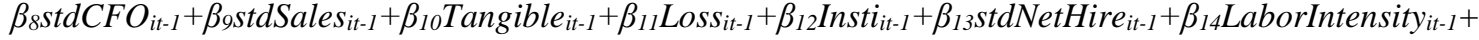
$\beta_{15}$ Union $_{i t-1}+\beta_{16}$ AbInvest ${ }_{i t}+\varepsilon_{i t}$

\begin{tabular}{|c|c|c|c|c|c|c|}
\hline \multirow[t]{2}{*}{ Variables } & \multicolumn{3}{|c|}{$\begin{array}{c}(1) \\
\text { Cscore }=\text { Acsore }\end{array}$} & \multicolumn{3}{|c|}{$\begin{array}{c}(2) \\
\text { Cscore }=\text { Negative NOA }\end{array}$} \\
\hline & Coeff. & & $T$-stat & Coeff. & & $T$-stat \\
\hline Intercept & 0.057 & $* * *$ & 3.68 & 0.083 & $* * *$ & 3.74 \\
\hline Cscore-1 & -0.016 & $* * *$ & -2.97 & -0.022 & $* * *$ & -2.78 \\
\hline$F R Q_{t-1}$ & -0.012 & $* * *$ & -4.00 & -0.006 & & -1.28 \\
\hline$M t \vec{B}_{t-1}$ & 0.005 & $* * *$ & 4.69 & 0.005 & $* * *$ & 3.30 \\
\hline Sizet & -0.008 & $* * *$ & -10.83 & -0.007 & $* * *$ & -6.94 \\
\hline Quick $_{t-1}$ & 0.027 & $* * *$ & 34.81 & 0.027 & $* * *$ & 25.79 \\
\hline Leverage $_{t-1}$ & 0.059 & $* * *$ & 9.13 & 0.051 & $* * *$ & 5.28 \\
\hline Dividend $_{t-1}$ & -0.013 & $* * *$ & -6.00 & -0.013 & $* * *$ & -3.75 \\
\hline$s t d C F O_{t-1}$ & 0.209 & $* * *$ & 8.66 & 0.195 & $* * *$ & 5.81 \\
\hline stdSalest-1 & 0.010 & $* *$ & 2.50 & 0.013 & $* *$ & 2.16 \\
\hline Tangible $t-1_{1}$ & -0.004 & & -1.28 & -0.002 & & -0.53 \\
\hline $\operatorname{LosS}_{t-1}$ & 0.034 & $* * *$ & 14.05 & 0.037 & $* * *$ & 10.14 \\
\hline stdNetHire $_{t-1}$ & 0.069 & $* * *$ & 10.50 & 0.071 & $* * *$ & 7.16 \\
\hline LaborIntensity $_{t-1}$ & 0.022 & & 0.73 & -0.012 & & -0.55 \\
\hline Union $_{t-1}$ & -0.031 & $* * *$ & -2.65 & -0.042 & $* *$ & -2.04 \\
\hline Instit-1 & -0.019 & $* * *$ & -4.15 & -0.019 & $* * *$ & -2.85 \\
\hline abInvest $t_{t-1}$ & 0.080 & $* * *$ & 7.85 & 0.001 & & 0.12 \\
\hline MAScore $t-1$ & 0.002 & & 0.58 & 0.091 & $* * *$ & 6.31 \\
\hline Year Fixed Effects & & Yes & & & Yes & \\
\hline Industry Fixed Effects & & Yes & & & Yes & \\
\hline $\operatorname{Adj} R^{2}$ & & $23.54 \%$ & & & $22.62 \%$ & \\
\hline$N$ & & 31,425 & & & 16,434 & \\
\hline
\end{tabular}

This table reports the results of estimating model (5) using two alternative proxies of conservatism, Acsore and Negative NOA. All variables are as defined in Appendix A. $p$-values are based on two-tailed tests, with standard errors clustered by firm. 
TABLE 5

The regression model:

\section{Controlling for Managerial Ability and Corporate Governance}

AbsAbNetHire $_{t}=\beta_{0}+\beta_{1}$ Cscore $_{i t-1}+\beta_{2}$ FR $_{i t-1}+\beta_{3}$ MtB $_{i t-1}+\beta_{4}$ Size $_{i t-1}+\beta_{5}$ Quick $_{i t-1}+\beta_{6}$ Leverage $_{i t-1}+\beta_{7}$ Dividend $_{i t-1}+$ $\beta_{8 s t d C F O}{ }_{i t-1}+\beta_{9}$ stdSales $_{i t-1}+\beta_{10}$ Tangible $_{i t-1}+\beta_{11}$ Loss $_{i t-1}+\beta_{12}$ Instit $_{i t-1}+\beta_{13}$ stdNetHire ${ }_{i t-1}+\beta_{14}$ LaborIntensity $_{i t-1}+$ $\beta_{15}$ Union $_{i t-1}+\beta_{16}$ abInvest $_{i t}+\beta_{17}$ MAscore $_{i t}+\beta_{18}$ Gindex $_{i t}+\varepsilon_{i t}$

\begin{tabular}{|c|c|c|c|c|c|c|c|}
\hline \multirow[b]{3}{*}{ Intercept } & \multicolumn{3}{|c|}{$\begin{array}{c}\text { (1) } \\
\text { Controlling for } \\
\text { Managerial Ability }\end{array}$} & \multirow[t]{3}{*}{ Variables } & \multicolumn{3}{|c|}{$\begin{array}{c}\text { (2) } \\
\text { Controlling for } \\
\text { Managerial Ability and } \\
\text { Corporate Governance }\end{array}$} \\
\hline & \multicolumn{2}{|l|}{ Coeff. } & t-stat & & \multicolumn{2}{|c|}{ Coeff. } & \multirow{2}{*}{$\frac{t \text {-stat }}{3.36}$} \\
\hline & 0.097 & **** & 5.78 & & 0.100 & $* * *$ & \\
\hline Cscore $_{t-1}$ & -0.038 & $* * *$ & -6.14 & Cscoret $_{t-1}$ & -0.029 & $* * *$ & -3.49 \\
\hline$F R Q_{t-1}$ & -0.012 & $* * *$ & -3.80 & $F R Q_{t-1}$ & -0.008 & $* *$ & -2.00 \\
\hline $\operatorname{MtB}_{t-1}$ & 0.003 & $* * *$ & 2.94 & $\boldsymbol{M t} \widetilde{B}_{t-1}$ & 0.002 & & 1.28 \\
\hline Size $_{t-1}$ & -0.012 & $* * *$ & -12.09 & Size $_{t-1}$ & -0.011 & $* * *$ & -8.26 \\
\hline Quick $_{t-1}$ & 0.027 & $* * *$ & 34.42 & Quick $_{t-1}$ & 0.026 & $* * *$ & 20.4 \\
\hline Leverage $_{t-1}$ & 0.060 & $* * *$ & 9.33 & $\operatorname{Lev}_{t-1}$ & 0.064 & $* * *$ & 6.93 \\
\hline Dividend $_{t-1}$ & -0.012 & $* * *$ & -5.54 & Dividend $_{t-1}$ & -0.008 & $* * *$ & -2.63 \\
\hline$s t d C F O_{t-1}$ & 0.208 & $* * *$ & 8.64 & $s t d C F O_{t-1}$ & 0.212 & $* * *$ & 5.10 \\
\hline stdSales $_{t-1}$ & 0.011 & $* * *$ & 2.61 & stdSales $_{t-1}$ & 0.011 & & 1.64 \\
\hline Tangible $_{t-1}$ & -0.004 & & -1.14 & Tangible $_{t-1}$ & 0.000 & & 0.01 \\
\hline $\operatorname{Loss}_{t-1}$ & 0.036 & $* * *$ & 14.56 & $\operatorname{Loss}_{t-1}$ & 0.032 & $* * *$ & 8.69 \\
\hline stdNetHire $_{t-1}$ & 0.069 & $* * *$ & 10.56 & stdNetHire $_{t-1}$ & 0.072 & $* * *$ & 7.67 \\
\hline LaborIntensityt-1 & 0.017 & & 0.57 & LaborIntensity $_{t-1}$ & -0.087 & $* *$ & -2.45 \\
\hline Union $_{t-1}$ & -0.026 & $* *$ & -2.23 & Union $_{t-1}$ & -0.025 & $*$ & -1.69 \\
\hline Instit-1 & -0.023 & $* * *$ & -4.92 & Instit-1 & -0.012 & $*$ & -1.95 \\
\hline abInvest $_{t-1}$ & 0.071 & $* * *$ & 7.00 & abInvest $_{t-1}$ & 0.053 & $* * *$ & 3.82 \\
\hline \multirow[t]{2}{*}{ MAscore } & 0.001 & & 0.33 & MAscore & 0.010 & $* *$ & 2.17 \\
\hline & & & & Gindex & 0.000 & & 0.76 \\
\hline Year Fixed Effects & & Yes & & & & Yes & \\
\hline Industry Fixed Effects & & Yes & & & & Yes & \\
\hline $\operatorname{Adj} . R^{2}$ & & $4.11 \%$ & & $\operatorname{Adj} . R^{2}$ & & $25.75 \%$ & \\
\hline$N$ & & 31,406 & & $N$ & & 15,617 & \\
\hline
\end{tabular}

This table presents the results of estimating model (5), controlling for managerial ability (MAscore) and corporate governance (Gindex). All variables are as defined in Appendix A. p-values are based on two-tailed tests, with standard errors clustered by firm. 
The regression model:

TABLE 6

Controlling for Other Investments

AbsAbNetHire $_{t}=\beta_{0}+\beta_{1}$ Cscore $_{i t-1}+\beta_{2}$ FRQ $_{i t-1}+\beta_{3}$ MtB $_{i t-1}+\beta_{4}$ Size $_{i t-1}+\beta_{5}$ Quick $_{i t-1}+\beta_{6}$ Leverage $_{i t-1}+\beta_{7}$ Dividend $_{i t-1}+$

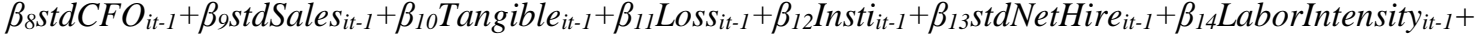
$\beta_{15}$ Union $_{i t-1}+\beta_{16}$ AbInvest $_{i t}+\varepsilon_{i t}$

\begin{tabular}{|c|c|c|c|c|c|c|}
\hline \multirow[t]{2}{*}{ Variables } & \multicolumn{3}{|c|}{$\begin{array}{c}\text { (1) } \\
\text { When NetHire is } \\
\text { positively related to } \\
\text { change in investment }\end{array}$} & \multicolumn{3}{|c|}{$\begin{array}{c}(2) \\
\text { When NetHire is } \\
\text { negatively related to } \\
\text { change in investment }\end{array}$} \\
\hline & Coeff. & & t-stat & Coeff. & & $t$-stat \\
\hline Intercept & 0.105 & $* * *$ & 4.09 & 0.090 & $* * *$ & 2.91 \\
\hline Cscore $_{t-1}$ & -0.040 & $* * *$ & -5.38 & -0.037 & $* * *$ & -4.30 \\
\hline$F R Q_{t-1}$ & -0.008 & $* *$ & -1.99 & -0.018 & $* * *$ & -3.71 \\
\hline$M t \boldsymbol{B}_{t-1}$ & 0.004 & $* * *$ & 4.18 & 0.002 & $*$ & 1.82 \\
\hline Size $_{t-1}$ & -0.012 & $* * *$ & -9.53 & -0.011 & $* * *$ & -7.83 \\
\hline Quick $_{t-1}$ & 0.025 & $* * *$ & 35.73 & 0.028 & $* * *$ & 37.47 \\
\hline Leverage $_{t-1}$ & 0.074 & $* * *$ & 11.02 & 0.046 & $* * *$ & 7.12 \\
\hline Dividend $_{t-1}$ & -0.015 & $* * *$ & -4.75 & -0.009 & $* *$ & -2.48 \\
\hline$s t d C F O_{t-1}$ & 0.208 & $* * *$ & 7.88 & 0.222 & $* * *$ & 7.55 \\
\hline stdSales $_{t-1}$ & 0.010 & $* *$ & 2.27 & 0.010 & $*$ & 1.93 \\
\hline Tangible $_{t-1}$ & -0.003 & & -0.72 & -0.007 & & -1.62 \\
\hline $\operatorname{Loss}_{t-1}$ & 0.031 & $* * *$ & 10.27 & 0.041 & $* * *$ & 12.01 \\
\hline stdNetHire $_{t-1}$ & 0.069 & $* * *$ & 9.69 & 0.071 & $* * *$ & 8.95 \\
\hline LaborIntensity $_{t-1}$ & -0.010 & & -0.30 & 0.042 & & 1.36 \\
\hline Union $_{t-1}$ & -0.039 & $* *$ & -2.24 & -0.017 & & -0.83 \\
\hline Insti $t_{t-1}$ & -0.021 & $* * *$ & -3.50 & -0.027 & $* * *$ & -4.18 \\
\hline abInvest $_{t-1}$ & 0.066 & $* * *$ & 5.27 & 0.091 & $* * *$ & 7.13 \\
\hline Year Fixed Effects & & Yes & & & Yes & \\
\hline Industry Fixed Effects & & Yes & & & Yes & \\
\hline $\operatorname{Adj} . R^{2}$ & & $.45 \%$ & & & $7.63 \%$ & \\
\hline$N$ & & 8,274 & & & 12,484 & \\
\hline
\end{tabular}

This table presents the results of estimating model (5) across the subsamples when NetHire is positively and negatively related to change in investment. All variables are as defined in Appendix A. $p$-values are based on twotailed tests, with standard errors clustered by firm. 
TABLE 7

The regression model:

\section{Examining SAB No. 101 as an Exogenous Shock of Conservatism}

AbsAbNetHire $_{t}=\beta_{0}+\beta_{1} S A B_{i t-1}+\beta_{2}$ FRQ $_{i t-1}+\beta_{3}$ MtB $_{i t-1}+\beta_{4}$ Size $_{i t-1}+\beta_{5}$ Quick $_{i t-1}+\beta_{6}$ Leverage $_{i t-1}+\beta_{7}$ Dividend $_{i t-1}+$ $\beta_{8 s t d C F O}$ it- $-1+\beta_{9}$ stdSales $_{i t-1}+\beta_{10}$ Tangible $_{i t-1}+\beta_{11}$ Loss $_{i t-1}+\beta_{12}$ Insti $_{i t-1}+\beta_{13 \text { stdNetHire }}{ }_{i t-1}+\beta_{14}$ LaborIntensity $_{i t-1}+$ $\beta_{15}$ Union $_{i t-1}+\beta_{16}$ AbInvest $_{i t}+\varepsilon_{i t}$

\begin{tabular}{|c|c|c|c|}
\hline Variables & Coeff. & & $t$-stat \\
\hline$S A B$ & -0.008 & $* * *$ & -2.71 \\
\hline$F R Q_{t-1}$ & -0.012 & $* * *$ & -3.71 \\
\hline$M t \bar{B}_{t-1}$ & 0.006 & $* * *$ & 6.85 \\
\hline Size $_{t-1}$ & -0.006 & $* * *$ & -4.75 \\
\hline Quick $_{t-1}$ & 0.028 & $* * *$ & 35.86 \\
\hline Leverage $_{t-1}$ & 0.057 & $* * *$ & 8.56 \\
\hline Dividend $_{t-1}$ & -0.001 & & -0.20 \\
\hline$s t d C F O_{t-1}$ & 0.055 & $* *$ & 2.03 \\
\hline stdSalest-1 & 0.015 & $* * *$ & 3.10 \\
\hline Tangible $_{t-1}$ & 0.016 & $* * *$ & 3.68 \\
\hline LosSt-1 & 0.025 & $* * *$ & 10.11 \\
\hline stdNetHiret-1 & -0.050 & $* * *$ & -7.10 \\
\hline LaborIntensity $_{t-1}$ & 0.033 & & 0.76 \\
\hline Uniont $t-1_{1}$ & -0.011 & & -0.60 \\
\hline Instit-1 $_{1}$ & -0.019 & $* * *$ & -2.94 \\
\hline abInvest $t_{t-1}$ & 0.023 & $* * *$ & 4.79 \\
\hline MAScore $t-1$ & 0.052 & $* * *$ & 5.08 \\
\hline Year Fixed Effects & & Yes & \\
\hline Industry Fixed Effects & & Yes & \\
\hline $\operatorname{Adj} . R^{2}$ & & $43.02 \%$ & \\
\hline$N$ & & 31,865 & \\
\hline
\end{tabular}

This table presents the results of using SAB No. 101 as an exogenous shock to increase accounting conservatism to further test the association between conservatism and labor investment inefficiency. In model (5), we replace Cscore with an indicator variable $S A B$, that equals one after the enactment of SAB 101 and zero otherwise, to repeat our analyses. All variables are as defined in Appendix A. $p$-values are based on two-tailed tests, with standard errors clustered by firm. 
TABLE 8

\section{Propensity Score Matching Analysis}

Panel A: The first stage

The regression model is:

Cscore_D $=\beta_{0}+\beta_{1} F R Q_{i, t-1}+\beta_{2}$ MtB $_{i, t-1}+\beta_{3}$ Size $_{i, t-1}+\beta_{4}$ Quick $_{i, t-1}+\beta_{5}$ Leverage $_{i, t-1}+\beta_{6}$ Dividend $_{i, t-1}+\beta_{7}$ stdCFO $_{i, t-1}+\beta_{8}$ stdSales${ }_{i, t-1}+\beta_{9}$ Tangible $_{i, t-1}+\beta_{10}$ Loss $_{i, t-1}+\beta_{11}$ Insti $_{i, t-1}+\beta_{12}$ stdNetHire $_{i, t-1}+\beta_{13}$ LaborIntensity $_{i, t-1}+\beta_{14}$ Union $_{i, t}+\beta_{15}$ AbInvest $_{i, t}+$ $\beta_{16}$ MAScore $e_{i, t}+\varepsilon_{i, t}$

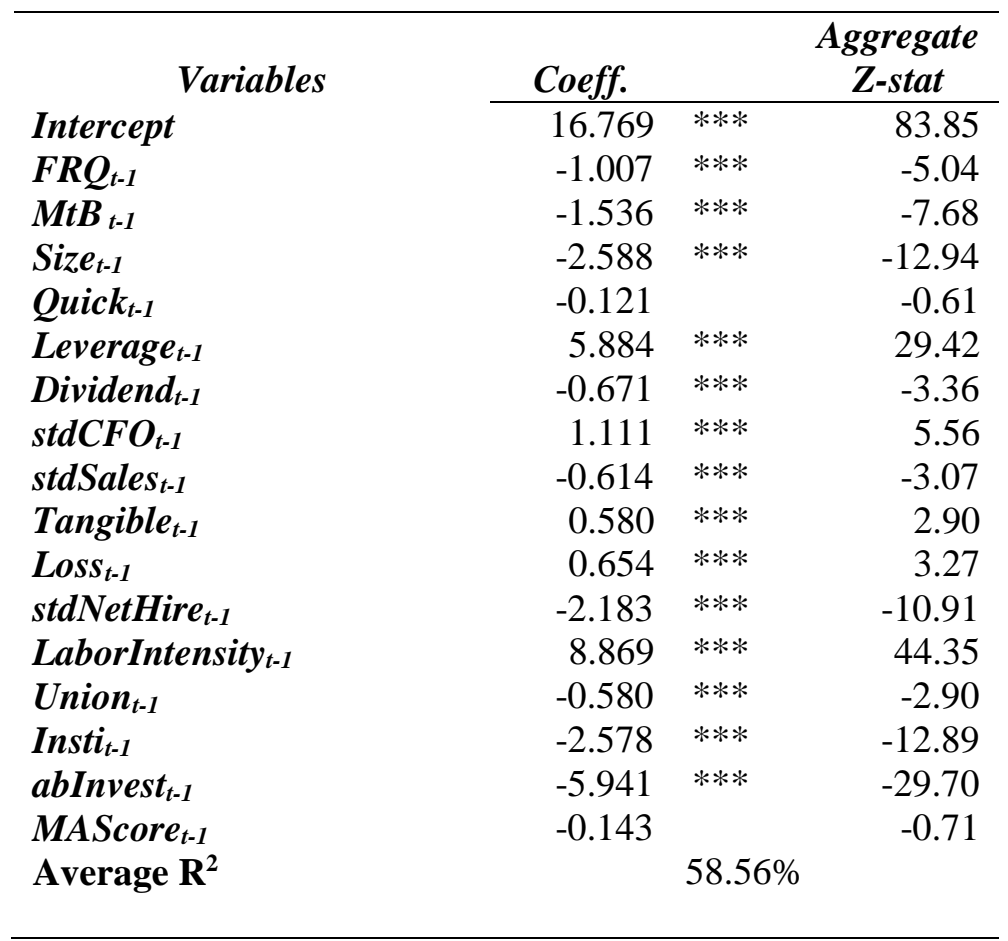

Panel B: The second stage

\begin{tabular}{lrlr}
\hline \multicolumn{1}{c}{ Variables } & \multicolumn{1}{c}{ Coeff. } & & \multicolumn{1}{c}{$\boldsymbol{t}$-stat } \\
\cline { 2 - 4 } Intercept $^{\text {Cscore }}$-1 & 0.168 & $* * *$ & 4.59 \\
FR $_{t-1}$ & $\mathbf{- 0 . 0 1 6}$ & $* * *$ & $\mathbf{- 2 . 9 9}$ \\
MtB $_{t-1}$ & -0.005 & & -0.52 \\
Size $_{t-1}$ & 0.002 & $*$ & 1.68 \\
Quick $_{t-1}$ & -0.009 & $* * *$ & -3.59 \\
Leverage $_{t-1}$ & 0.023 & $* * *$ & 12.11 \\
Dividend $_{t-1}$ & 0.015 & & 1.00 \\
stdCFO $_{t-1}$ & -0.032 & $* * *$ & -4.33 \\
stdSales $_{t-1}$ & 0.089 & & 1.50 \\
Tangible $_{t-1}$ & 0.034 & $* * *$ & 3.42 \\
Loss $_{t-1}$ & -0.012 & & -1.21 \\
stdNetHire $_{t-1}$ & 0.023 & $* * *$ & 3.52 \\
LaborIntensity $_{t-1}$ & 0.032 & $* *$ & 2.19 \\
Union $_{t-1}$ & -0.043 & & -1.40 \\
Insti $_{t-1}$ & -0.074 & & -1.63 \\
& -0.028 & $* *$ & -2.15
\end{tabular}




\begin{tabular}{|c|c|c|}
\hline abInvest $_{t-1}$ & 0.121 & $* * *$ \\
\hline MAScore $_{t-1}$ & -0.020 & $*$ \\
\hline Year Fixed Effects & & Yes \\
\hline Industry Fixed Effects & & Yes \\
\hline $\operatorname{Adj} . R^{2}$ & & $16.18 \%$ \\
\hline$N$ & & 4,388 \\
\hline
\end{tabular}

This table presents the results of propensity score matching analysis. In panel A, the first stage ordered logistic regression estimates of the determinants of conservatism. Cscore_D equals one if a firm's Cscore is above the industry-year median and zero otherwise. Column (1) reports the average coefficient estimate across year-specific estimation from 1986 through 2014. Column (2) reports an aggregate $z$-statistic, which is calculated as the sum of the individual annual $z$-statistics divided by the square root of the number of years over which model (6) is estimated (Armstrong, Guay, and Weber 2010). This aggregated z-statistic assumes that each annual estimation is independent of the other estimations. Panel B shows the results of using the propensity-score matching method to examine the association between labor investment inefficiency and conservatism. Coefficients are presented with $t$-statistics based on firm-clustered standard errors. $* * *, * *$ and $*$ denote significance at the 1,5 , and 10 percent levels, for one-tailed tests where there are predictions and two-tailed tests otherwise All variables are defined in Appendix A. 
TABLE 9

Abnormal Net Hiring and Future Performance

The regression model:

$\triangle R O A_{\text {iavg }(t+1, t+2, t+3)}=\beta_{0}+\beta_{1}$ absNetHire $_{i t}+\beta_{2}$ Cscore $_{i t}+\beta_{3}$ absNetHire $_{i t} *$ Cscore $_{i t}+$ $\left(\gamma_{1}+\gamma_{2} \mathrm{NetDFE} E_{i t}+\gamma_{3} \mathrm{NegDFE} E_{i t} * D F E_{i t}+\gamma_{4} \mathrm{PosDFE}_{i t} * D F E_{i t}\right) * D F E_{i t+}\left(\lambda_{1}+\lambda_{2} \mathrm{NegCE}_{i t}+\lambda_{3} \mathrm{NegCE}_{i t} * C E_{i t}+\right.$ $\left.\lambda_{4} \operatorname{Pos} C E_{i t} * C E_{i t}\right) * C E_{i t}+\varepsilon_{i t}$

\begin{tabular}{|c|c|c|c|c|c|c|}
\hline \multirow[t]{2}{*}{ Variables } & \multicolumn{3}{|c|}{$\begin{array}{c}(1) \\
\text { Dependent Variable }= \\
\text { Change in } R O A \text { at } t+1\end{array}$} & \multicolumn{3}{|c|}{$\begin{array}{c}(2) \\
\text { Dependent Variable }= \\
\text { Average change in } R O A \\
\text { over next } 3 \text { years }\end{array}$} \\
\hline & Coeff. & & $t$-stat & Coeff. & & t-stat \\
\hline Intercept & 0.006 & $*$ & 1.80 & 0.000 & $*$ & -0.36 \\
\hline AbsAbNetHire & -0.062 & $* * *$ & -6.78 & -0.023 & $* * *$ & -6.38 \\
\hline Cscore & -0.059 & $* * *$ & -5.35 & 0.002 & & 0.38 \\
\hline AbsAbNetHire ${ }^{*}$ sCscore & 0.190 & $* * *$ & 3.90 & 0.040 & $* *$ & 2.01 \\
\hline$D F E$ & -0.210 & $* * *$ & -3.97 & -0.183 & $* * *$ & -8.76 \\
\hline NegDFE & -0.018 & $* * *$ & -4.73 & -0.004 & $* * *$ & -2.67 \\
\hline NegDFE*DFE & -0.164 & $* * *$ & -2.65 & -0.076 & $* * *$ & -3.10 \\
\hline $\operatorname{NegDFE} E^{*} D F E * D F E$ & 0.128 & $* * *$ & 9.94 & 0.027 & $* * *$ & 5.77 \\
\hline$P o s D F E^{*} D F E * D F E$ & -1.178 & $* * *$ & -7.54 & -0.362 & $* * *$ & -5.17 \\
\hline$C E$ & 0.008 & & 0.44 & 0.028 & & 3.63 \\
\hline$N e g C E$ & -0.018 & $* * *$ & -5.78 & -0.004 & $* * *$ & -3.18 \\
\hline $\operatorname{Neg} C E^{*} C E$ & -0.256 & $* * *$ & -6.66 & -0.065 & $* * *$ & -4.19 \\
\hline $\operatorname{Neg} C E^{*} C E^{*} C E$ & -0.079 & $* * *$ & -6.71 & -0.024 & $* * *$ & -5.51 \\
\hline$P o s C E * C E * C E$ & 0.059 & $* * *$ & 8.30 & 0.014 & $* * *$ & 4.27 \\
\hline$A d j . R^{2}$ & & 3.00 & & & $.00 \%$ & \\
\hline No. Obs. & & 29,35 & & & 5,134 & \\
\hline
\end{tabular}

This table presents the results of estimating model (7) to examine the effect of abnormal net hiring on future performance. All variables are as defined in Appendix A. $p$-values are based on two-tailed tests, with standard errors clustered by firm. 
The regression model:

TABLE 10

The Role of Unionized Labor

AbsAbNetHire $_{t}=\beta_{0}+\beta_{1}$ Cscore $_{i t-1}+\beta_{2}$ FR $_{i t-1}+\beta_{3}$ MtB $_{i t-1}+\beta_{4}$ Size $_{i t-1}+\beta_{5}$ Quick $_{i t-1}+\beta_{6}$ Leverage $_{i t-1}+\beta_{7}$ Dividend $_{i t-1}+$

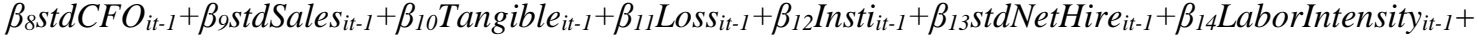
$\beta_{15}$ Union $_{i t-1}+\beta_{16}$ AbInvest $_{i t}+\varepsilon_{i t}$

\begin{tabular}{|c|c|c|c|c|c|c|c|c|}
\hline \multirow[t]{2}{*}{ Variables } & \multicolumn{3}{|c|}{$\begin{array}{c}\text { (1) } \\
\text { All firms }\end{array}$} & \multicolumn{3}{|c|}{$\begin{array}{c}\text { (2) } \\
\text { Firms with positive } \\
\text { expected net hiring }\end{array}$} & \multicolumn{2}{|c|}{$\begin{array}{c}\text { (3) } \\
\text { Firms with negative } \\
\text { expected net hiring }\end{array}$} \\
\hline & Coeff. & & $t$-stat & Coeff. & & $t$-stat & Coeff. & $t$-stat \\
\hline \multicolumn{9}{|c|}{ High Unionization Subsample } \\
\hline Cscore & -0.037 & $* *$ & -2.53 & -0.077 & $* * *$ & -3.81 & 0.019 & 1.00 \\
\hline Control Variables & & & Yes & & & Yes & & Yes \\
\hline Year Fixed Effects & & & Yes & & & Yes & & Yes \\
\hline Industry Fixed Effects & & & Yes & & & Yes & & Yes \\
\hline Adj. $R^{2}$ & & & $23.82 \%$ & & & $22.23 \%$ & & $29.12 \%$ \\
\hline $\mathrm{N}$ & & & 18,677 & & & 12,799 & & 5,878 \\
\hline \multicolumn{9}{|c|}{ Low Unionization Subsample } \\
\hline Cscore & -0.074 & $* * *$ & -3.35 & -0.074 & $* * *$ & -2.67 & -0.056 & -1.56 \\
\hline Control Variables & & & Yes & & & Yes & & Yes \\
\hline Year Fixed Effects & & & Yes & & & Yes & & Yes \\
\hline Industry Fixed Effects & & & Yes & & & Yes & & Yes \\
\hline Adj. $\mathrm{R}^{2}$ & & & $24.26 \%$ & & & $23.89 \%$ & & 2.77 \\
\hline $\mathrm{N}$ & & & 13,188 & & & 9,825 & & 3,363 \\
\hline
\end{tabular}


The regression model:

Table 11

\section{Considering Job Adjustment Cost}

AbsAbNetHire $_{t}=\beta_{0}+\beta_{1}$ Cscore $_{i t-1}+\beta_{2}$ FRQ $_{i t-1}+\beta_{3}$ MtB $_{i t-1}+\beta_{4}$ Size $_{i t-1}+\beta_{5}$ Quick $_{i t-1}+\beta_{6}$ Leverage $_{i t-1}+\beta_{7}$ Dividend $_{i t-1}+$

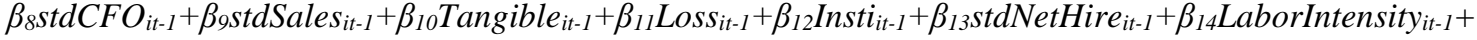
$\beta_{15}$ Union $_{i t-1}+\beta_{16}$ AbInvest $_{i t}+\varepsilon_{i t}$

\begin{tabular}{|c|c|c|c|c|c|c|}
\hline \multirow[t]{2}{*}{ Variables } & \multicolumn{3}{|c|}{$\begin{array}{c}\text { Low } \\
\text { Job Adjustment Costs }\end{array}$} & \multicolumn{3}{|c|}{$\begin{array}{c}\text { High } \\
\text { Job Adjustment Costs }\end{array}$} \\
\hline & Coeff. & & t-stat & Coeff. & & $t$-stat \\
\hline Intercept & 0.052 & $* * *$ & 2.73 & 0.057 & $* * *$ & 3.16 \\
\hline Cscore $_{t-1}$ & -0.024 & $*$ & -1.72 & -0.071 & $* * *$ & -3.26 \\
\hline$F R Q_{t-1}$ & -0.014 & $* * *$ & -3.71 & -0.010 & $*$ & -1.80 \\
\hline $\operatorname{MtB}_{t-1}$ & 0.007 & $* * *$ & 3.50 & 0.002 & & 1.38 \\
\hline Size $_{t-1}$ & -0.009 & $* * *$ & -7.79 & -0.008 & $* * *$ & -5.38 \\
\hline Quick $_{t-1}$ & 0.027 & $* * *$ & 16.91 & 0.028 & $* * *$ & 34.13 \\
\hline Leverage $_{t-1}$ & 0.048 & $* * *$ & 5.23 & 0.063 & $* * *$ & 5.71 \\
\hline Dividend $_{t-1}$ & -0.015 & $* * *$ & -4.93 & -0.007 & & -1.56 \\
\hline$s t d C F O_{t-1}$ & 0.230 & $* * *$ & 6.07 & 0.178 & $* * *$ & 4.54 \\
\hline stdSales $_{t-1}$ & 0.008 & & 1.41 & 0.016 & $* *$ & 2.16 \\
\hline Tangible $_{t-1}$ & -0.010 & $* *$ & -1.97 & -0.006 & & -1.31 \\
\hline $\operatorname{Loss}_{t-1}$ & 0.031 & $* * *$ & 9.16 & 0.039 & $* * *$ & 9.62 \\
\hline stdNetHire $_{t-1}$ & 0.070 & $* * *$ & 7.29 & 0.056 & $* * *$ & 5.20 \\
\hline LaborIntensity $_{t-1}$ & -0.003 & & -0.16 & 0.432 & $* * *$ & 3.44 \\
\hline Union $_{t-1}$ & -0.044 & $* * *$ & -2.93 & 0.043 & & 1.00 \\
\hline Insti $_{t-1}$ & -0.015 & $* *$ & -2.41 & -0.025 & $* * *$ & -2.86 \\
\hline abInvest $t_{t-1}$ & 0.009 & & 1.63 & -0.009 & & -1.38 \\
\hline MAScore & 0.108 & $* * *$ & 7.04 & 0.056 & $* * *$ & 3.50 \\
\hline Year Fixed Effects & & Yes & & & Yes & \\
\hline Industry Fixed Effects & & Yes & & & Yes & \\
\hline $\operatorname{Adj} . R^{2}$ & & $5.57 \%$ & & & $0.04 \%$ & \\
\hline $\boldsymbol{N}$ & & 6,001 & & & 15,864 & \\
\hline $\begin{array}{l}\text { Difference between firn } \\
(t-\text { stat }=-1.77, p<0.1)\end{array}$ & th low & higl & & & & \\
\hline
\end{tabular}

This table presents the results of estimating model (5) for low vs. high job adjustment cost subsamples. Job adjustment costs are measured based on the industry-specific index of reliance on skilled labors. Details are discussed in section 5.4.3. All variables are defined in Appendix A. All p-values are based on two-tailed tests. 